SJ Quinney College of Law, University of Utah Utah Law Digital Commons

$5-2020$

Resilience Theory and Wicked Problems

Robin Kundis Craig

Follow this and additional works at: https://dc.law.utah.edu/scholarship

Part of the Environmental Law Commons 


\title{
Resilience Theory and Wicked Problems
}

\section{Robin Kundis Craig*}

\begin{abstract}
This Article posits, first, that resilience theory offers important insights into our understanding of wicked problems and, second, that to understand the value of resilience theory to wicked problems, we should start by going back to the context of Rittel's and Webber's 1973 delineation of the ten characteristics of a "wicked problem." Rittel and Webber were in fact among the vanguard of researchers beginning to articulate the realization that social and ecological systems-now social-ecological systems, or SESs-do not follow the predictable and mechanistic rules of Newtonian physics. As a result, SESs do not yield, at least not over the long term, to engineering-based "solutions" designed to satisfy contemporary priorities and desires. Instead, like resilience theorists, although lacking resilience theory's vocabulary, Rittel and Webber acknowledged that change is the norm for both social and ecological systems and that the realities of complex adaptive social-ecological systems make "once and done" planning and management impossible.
\end{abstract}

In re-reading Rittel and Webber almost 50 years later, however, it becomes useful to pull apart the blending of social capriciousness and ecological panarchy that for them together added up to "wickedness" in social problem solving. Social capriciousness-the fact that social priorities and desires can both evolve over time and flip in response to political events such as elections-has become the far more accepted component of "wickedness"; few anymore expect social "solutions" to persist indefinitely. However, that same acceptance of continual, often unpredictable, change has not yet translated to the ecological side of wicked problems-which is precisely why resilience theory can help 21st-century citizens to formulate more productive approaches to those problems.

\footnotetext{
* James I. Farr Presidential Endowed Professor of Law, University of Utah S.J. Quinney College of Law, Salt Lake City, Utah. I would like to thank J.B. Ruhl, Jim Salzman, and the Vanderbilt Law Review members for their invitation to participate in the October 2019 symposium on wicked problems, as well as the participants in that symposium for their helpful comments. The author may be reached at robin.craig@law.utah.edu.
} 


\section{INTRODUCTION}

In 1973, Horst W.J. Rittel and Melvin M. Webber published "Dilemmas in a General Theory of Planning," generally earning credit for defining the characteristics of a "wicked problem." While Rittel and Webber originally thought of wicked problems in terms of social planning, the concept has now becomeappropriately or inappropriately - ubiquitous, ${ }^{2}$ describing problems as varied as water management, ${ }^{3}$ foreign policy, ${ }^{4}$ integration of immigration policies, ${ }^{5}$ fisheries management, ${ }^{6}$ and climate change. ${ }^{7}$

The 50th anniversary of Rittel's and Webber's seminal article is quickly approaching, suggesting an appropriate occasion for re-examining their understanding of wicked problems in light of the 21 st century and the increasing embrace of the concept of the "Anthropocene" - the realization that humans have set in motion planetary-scale changes in almost every life-support system, from the

\footnotetext{
${ }^{1}$ Horst W.J. Rittel \& Melvin M. Webber, Dilemmas in a General Theory of Planning, 4 PoLICY SCIENCES 155 (1973).

${ }^{2}$ See, e.g., Catrien J. A. M. Termeer, Art Dewulf, Gerard Breeman, and Sabina J. Stiller, Governance Capabiilities for Dealing Wisely with Wicked Problems, 47:6 AdMinistration \& Society 680, 681 (2015) (providing a more comprehensive list than this article does).

${ }^{3}$ E.g., Denise Lach, Steve Rayner, \& Helen Ingram, Taming the waters: Strategies to domesticate the wicked problems of water resource management, 3 INTL. J. WATER 1-17 (2005), DOI: 10.1504/IJW.2005.007156

${ }^{4}$ E.g., Nancy C. Roberts, Wicked problems and network approaches to resolution, 1 INTL. PUBLIC MANAGEMENT ReV. 1-19 (2000).

${ }^{5}$ E.g., Caelestra Poppelaars \& Peter Scholten, Two worlds apart: The divergence of national and local immigrant integration policies in the Netherlands, 40 ADMINISTRATION \& SOCIETY 335-357 (2008), https://doi.org/10.1177/0095399708317172.

${ }^{6}$ E.g., Ahmed S. Khan \& Barb Neis, The rebuilding imperative in fisheries: Clumsy solutions for a wicked problem?, 87 PROGRESS IN OCEANOGRAPHY 347-56 (2010), doi:10.1016/j.pocean.2010.09.012; Svein Jentofta \& Ratana Chuenpagdee, Fisheries and coastal governance as a wicked problem, 33 MARINE POLICY 553-560 (2009), https://doi.org/10.1016/j.marpol.2008.12.002.

${ }^{7}$ E.g., David G. Angeler, Craig R. Allen, Ahjond S. Garmestani, Lance H. Gunderson, \& Igor Linkov, Panarchy use in environmental science for risk and resilience planning, 36 ENVTL. SYS. Decisions 225, 225 (2016), DOI 10.1007/s10669-016-9605-6; Catrien J.A.M. Termeer, Art Dewulf \& Gerard Breeman, Governance of Wicked Climate Adaptation Problems, in J. KNIELING \& W. L. Filho, eds., Climate Change Governance 27-41 (2012); Richard j. Lazarus, Super wicked problems and climate change: Restraining the Present to Liberate the Future, 94 CORNELL L. REV. 1153-1235 (2008).

${ }^{8}$ Joseph Stromberg, What Is the Anthropocene and Are We in It?, Smithsonian Magazine, https://www.smithsonianmag.com/science-nature/what-is-the-anthropocene-and-are-we-in-it$\underline{164801414 /(J a n . ~ 2013) .}$
} 
atmosphere and climate change ${ }^{9}$ to the ocean and ocean acidification ${ }^{10}$ to the global distribution of toxics, ${ }^{11}$ plastics, ${ }^{12}$ and hormone mimickers ${ }^{13}$ into nearly every chemical and biological process on the planet, including the (seemingly) remote ecosystems of the Antarctic. ${ }^{14}$

From this context, what is most profoundly insightful about Rittel's and Webber's 1973 article is its continual attempts to grapple with the then-relativelynew perception of social change. Indeed, read with Anthropocenic eyes, Rittel's and Webber's characterization of "wicked problems" is a lament over the serious realization that there is no quantifiable, permanent "reality" (as in physics) or unmalleable set of rules (as in chess or math) against which to judge the success of new social policies or planning efforts. Instead, "solutions" to problems like traffic and crime may work for a while, but only until social or political conditions change. Thus, for example, road or freeway systems in cities subject to intensifying population growth and density may come to look like a "bad" choice that makes retrofitting for mass urban public transit harder and more expensive to implement. ${ }^{15}$ In addition, implemented solutions may set in motion follow-on problems at different scales or in different policy arenas, as has been the case for almost all water engineering anywhere in the world. ${ }^{16}$

${ }^{9}$ Intergovernmental Panel on Climate Change, Climate Change 2014: Synthesis Report 2-31 (2014).

10 Intergovernmental Panel on Climate Change, Special Report on the Ocean and Cryosphere in a CHANGING Climate 6-35 (2019).

${ }^{11}$ E.g., Frank Wania \& Donald Mackay, Tracking the Distribution of Persistent Organic Pollutants, 30:9 ENVTL. SCIENCE \& TECH. 390-96 (1996), available at https://sites.duke.edu/malaria/files/2012/07/Wania MacKay19961.pdf.

${ }_{12}$ E.g., Fauziah Shahul Hamid, Mehran Sanam Bhatti, Norkhairiyah Anuar, Norkhairah Anuar, Priya Mohan, \& Agamuthu Periathamby, Worldwide distribution and abundance of microplastic: How dire is the situation?, 36:10 WASTE MANAGEMENT \& RESEARCH 873-97 (2018), https://doi.org/10.1177/0734242X18785730.

${ }^{13}$ E.g., Ioanna Katsikantami, Stavros Sifakis, Manolis N. Tzatzarakis, ElenaVakonaki, Olga-Ioanna Kalantzi, Aristidis M. Tsatsakis, \& Apostolos K. Rizos, A global assessment of phthalates burden and related links to health effects, 97 ENVT. INTL. 216-236 (Dec. 2016), https://doi.org/10.1016/j.envint.2016.09.013.

14 Matthew Taylor, "Antarctica: plastic contamination reaches Earth's last wilderness," The Guardian, $\quad$ https://www.theguardian.com/environment/2018/jun/06/antarctica-plasticcontamination-reaches-earths-last-wilderness (June 6, 2018).

15 E.g., Sakdirat Kaewunruen, Joseph M. Sussman \& Akira Matsumoto, Grand Challenges in Transportation and Transit Systems, 2 FrontIERS IN BUILT ENVT. art. 4 (Feb. 2016), https://doi.org/10.3389/fbuil.2016.00004.

${ }^{16}$ E.g., The Downside of Dams: Is the Environmental Price of Hydroelectric Power Too High?, SCIENTIFIC AMERICAN, https://www.scientificamerican.com/article/how-do-dams-hurt-rivers/ (Sept. 18, 2012). 
To read Rittel and Webber nearly 50 years later, in other words, is to be retransported to the age, and the world-view, of the Engineer. ${ }^{17}$ Perhaps more precisely, reading Rittel and Webber now allows one to experience the initial anxiety attending the discovery that engineering solutions were never going to be enough to [permanently] "solve" social problems. Writing at a moment of particularly acute and obvious social upheaval in the United States - a factual context fully incorporated into the article-Rittel and Webber describe wicked problems as, essentially, the result of both social change, which provides the focus for Part II, and complex systems and their dynamism, which Part III will explore in more detail.

Rittel's and Webber's conflation of two sources of dynamism in wicked problems, which this Article labels as "social capriciousness"18 and "ecological panarchy," is important. These two dynamisms represent the two components of social-ecological systems, or SESs. The term "SES" acknowledges that human social systems always exist embedded within and interacting with a series of ecological systems, ${ }^{19}$ with both sets of systems operating at a variety of spatial and temporal scales. ${ }^{20}$ As Part II will explore in more detail, Rittel's and Webber's social capriciousness dynamic is a recognition that in a pluralistic and diverse society such as the United States, social goals and the metrics for evaluating "progress" are themselves often contested and hence are subject to both rapid changes (as after elections) and more gradual evolution. Notably, since 1973, most Americans have come to accept at least some level of social and cultural change as normal and expected-whether such change takes the form of new technology, evolving civil rights, acceptable social behavior, or any number of other continually evolving aspects of being a 21 st-century resident of the United States. ${ }^{21}$ In other

\footnotetext{
${ }^{17}$ The Engineer encompasses a perspective on ecosystems and SESs that assumes full human control over natural resources management, including the full reversibility of any changes that human make. For a fuller critique of this perspective, see MELINDA HARM BENSON \& ROBIN KUNDIS CRAIG, THE END OF SUSTAINABILITY: RESILIENCE AND THE FuturE OF ENVIRONMENTAL GOVERNANCE IN THE ANTHROPOCENE 14-18, 24-47, 56-60 (2017).

18 “Capriciousness" here attempts to capture both Rittel's and Webber's palpable uneasiness about the loss of social consensus (as Part II notes, their "blacks" and "students" are "revolting") and the attendant loss of an uber normative/ethical/religious framework against which to evaluate the emerging new values and priorities as against the old-i.e., the growing inability to assert with any clear authority whether values like "efficiency" are "better" than values like "equity."

19 Brian Walker \& David Salt, Resilience Thinking: Sustaining Ecosystems and People IN A CHANGING WORLD 1, 32-34 (2006).

${ }^{20} \mathrm{Id}$. at 88-93.

${ }^{21}$ Many of these Article's observations are not idiosyncratic to the United States and will apply in many societies. However, because Rittel and Webber themselves focused on the United States, and because this Article cannot possibly adequately identify, let alone discuss, important variations in social worldviews around the world, it remains focused on the United States - with acute awareness that it is backgrounding important social variation even within the United States. Nevertheless, while important, these variations do not undermine the main points of this Article regarding the importance
} 
words, in the five decades since Rittel and Webber described wicked problems, American society has begun to internalize the social capriciousness dynamic, somewhat taming the "wickedness" of some wicked problems.

The same cannot (yet) be said for the ecological panarchy dynamic; similar expectations that change is an expected component of natural systems and SESs have not yet been fully internalized into Americans' mental models of realityincluding into law. However, that is exactly where resilience theory provides useful new models to better contextualize wicked problems. Indeed, the fact that Rittel and Webber began to articulate the challenges that complex systems pose to social problem solving underscores why resilience theory is relevant to wicked problems.

Thus, after Part II separates Rittel's and Webber's ten characteristics of wicked problems into the categories of social capriciousness and ecological panarchy, Part III explains resilience theory and its relevance to the ecological panarchy components of wicked problems. It ends by examining the most widely accepted 21st-century example of a wicked problem-climate change - to demonstrate how resilience theory can both deepen our understanding of and help shape our responses to that problem.

Part IV then examines approaches to governance and law that are emerging as social scientists and legal scholars seek to address both wicked problems and the Anthropocene. Given that continual change is a critical component of both phenomena, it is perhaps unsurprising that these scholars have repeatedly found resilience theory a helpful model of reality from which to work. At the same time, however, the progress from Rittel and Webber to these newer scholars also makes increasingly clear that one's view of reality - a complex of expectations and explanations generally denominated a "cultural narrative" 22 — shapes one's ability to cope with wicked problems. This Article thus concludes that, just as acceptance of social change can temper the "wickedness" of the social capriciousness components of wicked problems, so internalization of resilience theory can temper the apparent "wickedness" stemming from ecological panarchy.

\section{RE-READING RITTEL AND WEBBER IN THE 21ST CENTURY: WICKED Problems as a CONFlation OF TWO DyNAMisMs}

of resilience theory to our concepts of wicked problems - although implementing the required new mindset will inevitably vary in response to differing existing cultural norms and narratives.

22 "Cultural narratives are stories told at the societal level, deeply embedded stories that frame and contextualize events within a particular culture to help give them meaning. . . . [O]ur cultural narratives of change - what might be termed the cultural psychology of change - influence how we actually deal with ecological change." BENSON \& CRAIG, supra note 17, at 8. 
As the Introduction pointed out, to say that the concept of a "wicked problem" has caught on is a bit of an understatement. Indeed, the adoption of this popular term into so many contexts, with uses both technical and colloquial, has obscured its original context. ${ }^{23}$ That context, however, reveals much about how we might more productively think about wicked problems in the 21 st century. In particular, this Article suggests that it is important to remember that "wicked" problems are a human construct or perception, not an immutable facet of reality like the speed of light in a vaccum. Rittel and Webber described wicked problems from a particular cultural moment, and failure to appreciate that moment can reify the construct of "wicked problem" in ways that actually impede society's ability to effectively deal with problems so labeled. This Part seeks to recapture the context of Rittel's and Webber's 1973 article in order to then tease apart two very different dynamisms that are at work in their concept of a wicked problem-social capriciousness and ecological panarchy.

\section{A. The Context of Rittel's and Webber's Wicked Problems}

Rittel and Webber characterized "wicked" problems in response to what they perceived as an attack — an attack by the popular laity on professionals and their proffered solutions to a variety of social ills. Indeed, "Dilemmas in a General Theory of Planning" identifies these attacks as the occasion of its writing, noting from the beginning that "we've been hearing ever-louder public protests against the professions' diagnoses of the clients' problems, against professionally designed governmental programs, against professionally certified standards for the public services." 24

The general public, clearly, was restless - no longer content that professionals had greatly improved, if not actually solved, the relatively easy, consensus social ills: "The streets have been paved, and roads now connect all places; houses shelter virtually everyone; the dread diseases are virtually gone; clean water is piped into nearly every building; sanitary sewers carry wastes from them; schools and hospitals serve virtually every district; and so on." ${ }^{25}$ Instead, "the

23 "However whilst wicked problem terminology has been widely applied to diverse policy issues, there has been less interest in why it was developed, namely in response to the radically disrupted American society of the 1960s and 1970s and the authors' rejection of technological fixes being advanced to solve complex, chaotic problems." Kate Crowley \& Brian Head, "The Origins, Impacts, and Significance of "Wicked Problems,", The Policy Space, https://www.thepolicyspace.com.au/2017/22/230-the-origins-impact-and-significance-of-wickedproblems (22 Nov. 2017).

${ }^{24}$ Rittel \& Webber, supra note 1 , at 155.

${ }^{25} \mathrm{Id}$. at 156. Notably, this Article was written during the COVID-19 pandemic that began in the winter of 2019-2020, a fact that both casts an interesting gloss on Rittel's and Webber's assertion that professionals had eliminated the "dread diseases" and emphasizes the reality of socialecological change. The homelessness problem that emerged after 1973 and water disasters such as 
Americans' traditional faith in a guaranteed Progress is being eroded by the same waves that are wearing down old beliefs in the social order's inherent goodness and in history's intrinsic benevolence." 26

Indeed, just as multiple entities were completing efforts to define the next sets of consensus national goals, ${ }^{27}$ the whole notion of "national consensus" was falling apart. Critically, at the time Rittel and Webber described wicked problems, cultural diversity was not yet widely accepted as a positive value. Indeed, as the authors themselves note, "[ $\mathrm{t}]$ here was a time during the 'Fifties when the quasisociological literature was predicting a Mass Society-foreseen as a rather homogeneously shared culture in which most persons would share values and beliefs, would hold to common aims, would follow similar life-styles, and thus would behave in similar ways." 28 By 1973, however, cultural diversity was becoming visible - sometimes violently — as an American reality, and "the nation was buffeted by the revolt of the blacks, then by the revolt of the students, then by the widespread revolt against the war, more recently with a new consumerism and conservationism. All these movements were striking out at the underlying systemic processes of contemporary American society." 29 Moreover, "[i]n a style rather different from those of the systems analysts and the Presidential commissioners, participants in these revolts were seeking to restructure the value and goal systems that affect the distribution of social product and shape the directions of national policy." 30 The prior perception of a social consensus - in hindsight, probably best characterized as the white, male, and middle-class norm enshrined in "Leave It to Beaver" and other such cultural icons-was dissolving in the face of "the growing awareness of the nation's pluralism and of the differentiation of values that accompanies differentiation of publics." 31 In short, Rittel and Webber concluded, the very metrics that the public used to evaluate "progress" had changed: "The tests for efficiency, that were once so useful as measures of accomplishment, are being challenged by a renewed preoccupation with consequences for equity." 32

Rittel and Webber, in other words, were acutely conscious of the social changes occurring around them. These changes, moreover, had profound implications for the engineering view of social progress and the ability of society to mechanistically advance to "perfection." As the authors themselves pointed out:

occurred in Flint, Michigan, similarly underscore the impermanence of engineered solutions to even consensus problems.

${ }^{26} \mathrm{Id}$. at 156 .

${ }^{27} \mathrm{Id}$. at 157 .

${ }^{28} \mathrm{Id}$. at 167.

${ }^{29} \mathrm{Id}$. at 157.

${ }^{30} \mathrm{Id}$.

${ }^{31} I d$.

${ }^{32}$ Id. at 156. 
Professionalism has been understood to be one of the major instruments for perfectability, an agent sustaining the traditional American optimism. Based in modern science, each of the professions has been conceived as the medium through which the knowledge of science is applied. In effect, each profession has been seen as a subset of engineering. ${ }^{33}$

Rittel and Webber then enact the transition from this simplistic worldview of continuous progress to one grounded in complexity ${ }^{34}$ - the transition from Newtonian physics to Einstein and quantum theory, from engineering to ecology. The world of the Newtonian Engineer was a relatively simple place, where cause and effect were relatively easy to discern, explain, and tinker with and "efficiency was seen as a condition in which a specified task could be performed with low inputs of resources. . . Because it was fairly easy to get consensus on the nature of problems during the early industrial period, the task could be assigned to the technically skilled, who in turn could be trusted to accomplish the simplified endin-view." 35 However, "the classical paradigm of science and engineering-the paradigm that has underlain modern professionalism-is not applicable to the problems of open societal systems." 36 These non-Newtonian social planning problems were instead "inherently wicked." 37

\section{B. Ten Characteristics that Conflate Two Sources of Societal Dynamism}

To recap, then: social planning problems constitute wicked problems because they are not amenable to relatively simple engineering solutions grounded in Newtonian physics. Moreover, the fact that Rittel and Webber described wicked problems in the context of social upheaval and changing social values is important, because social dynamism is one of the sources of a problem's "wickedness."

Within this context of ever-more-visible cultural diversity, dissent, and complexity, Rittel and Webber famously identified ten characteristics of wicked problems:

" 1 . There is no definitive formulation of a wicked problem." 38

"2. Wicked problems have no stopping rule." 39

\footnotetext{
${ }^{33} \mathrm{Id}$. at 158

${ }^{34}$ Crowley \& Head, supra note 23.

${ }^{35}$ Rittel \& Webber, supra note 1 , at 158-59.

${ }^{36} \mathrm{Id}$. at 160.

${ }^{37} \mathrm{Id}$.

${ }^{38} I d$. at 161.

${ }^{39} \mathrm{Id}$. at 162.
} 
"3. Solutions to wicked problems are not true-or-false, but good-or-bad."40

"4. There is no immediate and no ultimate test of a solution to a wicked problem." 41

"5. Every solution to a wicked problem is a 'one-shot operation'; because there is no opportunity to learn by trial-and-error, every attempt counts significantly." 42

"6. Wicked problems do not have an enumerable (or an exhaustively describable) set of potential solutions, nor is there a well-described set of permissible operations that may be incorporated into the plan."43

"7. Every wicked problem is essentially unique." 44

"8. Every wicked problem can be considered to be a symptom of another problem."45

"9. The existence of a discrepancy representing a wicked problem can be explained in numerous ways. The choice of explanation determines the nature of the problem's resolution."46

"10. The planner has no right to be wrong." 47

Rittel and Webber presented these ten characteristics as a unifying description of wicked problems. From a 21 st-century perspective, however, these characteristics conflate two aspects of social-ecological reality with respect to social problems. First, Rittel and Webber characterize social problems as wicked because society, social norms, and social goals themselves change and evolve in the face of a diversifying populace, making it impossible to fully and finally define, let alone completely solve, those problems. This aspect of wicked problems acknowledges the social capriciousness dynamism - the idea that social norms, social values, and hence social goals and prioritizations can both generally evolve over time and, particularly in a pluralistic society like the United States, be the objects of ongoing political contest. Second, and more important for the role of resilience theory, Rittel and Webber characterize social problems as wicked because the world works not just through linear and mechanistic causation but also through complex systems and systems of such systems. ${ }^{48}$ Table 1 separates Rittel's and Webber's ten characteristics into these two sources of "wickedness."

\section{Table 1: Classifying the Sources of Wicked Problems' Characteristics}

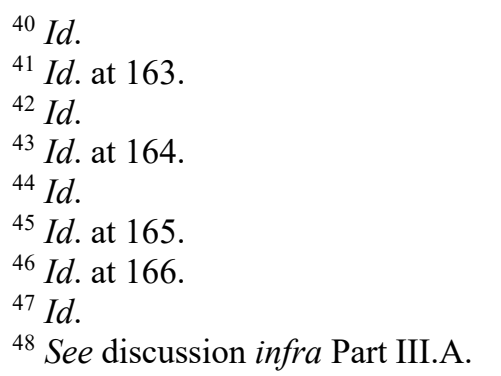




\begin{tabular}{|c|c|}
\hline $\begin{array}{c}\text { SOCIAL CAPRICIOUSNESS: } \\
\text { Characteristics Deriving from the } \\
\text { Fact that Society Evolves and Is } \\
\text { Political }\end{array}$ & $\begin{array}{l}\text { ECOLOGICAL PANARCHY: } \\
\text { Characteristics Deriving from the } \\
\text { Fact that Social-Ecological } \\
\text { Problems Participate in Complex } \\
\text { Systems }\end{array}$ \\
\hline $\begin{array}{l}\text { 1. There is no definitive formulation } \\
\text { of a wicked problem. } \\
\text { "The information needed to understand the } \\
\text { problem depends upon one's idea for } \\
\text { solving it. Problem understanding and } \\
\text { problem resolution are concomitant to } \\
\text { each other." In other words, no one can } \\
\text { definitively formulate what a social } \\
\text { problem is because diverse perspectives } \\
\text { matter to the very construction of the } \\
\text { problem and its potential solutions. As a } \\
\text { result, that definition can change-either } \\
\text { generally over time, as social norms } \\
\text { evolve, or specifically and relatively } \\
\text { suddenly in response to cultural inflection } \\
\text { points, such as elections, where new } \\
\text { political and social goals displace the old } \\
\text { ones. }\end{array}$ & $\begin{array}{l}\text { 4. There is no immediate and no } \\
\text { ultimate test of a solution to a } \\
\text { wicked problem. } \\
\text { "With wicked problems, ... any } \\
\text { solution, after being implemented, will } \\
\text { generate waves of consequences over an } \\
\text { extended-virtually an unbounded- } \\
\text { period of time. ... The full consequences } \\
\text { cannot be appraised until the waves of } \\
\text { repercussions have completely run out, } \\
\text { and we have no way of tracing all the } \\
\text { waves through all the affected lives } \\
\text { ahead of time or within a limited time } \\
\text { span." In other words, planning and } \\
\text { management actions occur within } \\
\text { complex systems, with not-fully- } \\
\text { predictable results. }\end{array}$ \\
\hline $\begin{array}{l}\text { 2. Wicked problems have no } \\
\text { stopping rule. } \\
\text { "[B]ecause there are no criteria for } \\
\text { sufficient understanding and because there } \\
\text { are no ends to the causal chains that link } \\
\text { interacting open systems, the would-be } \\
\text { planner can always try to do better." } 51 \\
\text { Thus, social problems have no stopping } \\
\text { rule because they are generally subject to } \\
\text { changing social and political demands over } \\
\text { time. }\end{array}$ & $\begin{array}{l}\text { 5. Every solution to a wicked problem } \\
\text { is a 'one-shot operation'; because } \\
\text { there is no opportunity to learn by } \\
\text { trial-and-error, every attempt counts } \\
\text { significantly. } \\
\text { "With wicked planning problems, ... } \\
\text { every implemented solution is } \\
\text { consequential. It leaves 'traces' that } \\
\text { cannot be undone. ... . . Whenever actions } \\
\text { are effectively irreversible and whenever } \\
\text { the half-lives of the consequences are } \\
\text { long, every trial counts. And every } \\
\text { attempt to reverse a decision or to correct } \\
\text { for the undesired consequences poses } \\
\text { another set of wicked problems, which } \\
\text { are in turn subject to the same } \\
\text { dilemmas." } 52 \text { Again, when acting within } \\
\text { complex systems, every action }\end{array}$ \\
\hline
\end{tabular}

${ }^{49} \mathrm{Id}$. at 161.

${ }^{50} \mathrm{Id}$. at 163 .

${ }^{51} \mathrm{Id}$. at 162.

${ }^{52} \mathrm{Id}$. at 163. 


\begin{tabular}{|c|c|}
\hline & $\begin{array}{l}\text { potentially alters system dynamics, } \\
\text { disallowing full reversibility. }\end{array}$ \\
\hline $\begin{array}{l}\text { 3. Solutions to wicked problems are } \\
\text { not true-or-false, but good-or-bad. } \\
\text { "Normally, many parties are equally } \\
\text { equipped, interested, and/or entitled to } \\
\text { judge the solutions, although none has the } \\
\text { power to set formal decision rules to } \\
\text { determine correctness. Their judgments are } \\
\text { likely to differ widely to accord with their } \\
\text { group or personal interests, their special } \\
\text { value-sets, and their ideological } \\
\text { predilections. Their assessments of } \\
\text { proposed solutions are expressed as 'good' } \\
\text { or 'bad' or, more likely, as 'better or } \\
\text { worse' or 'satisfying' or 'good enough.'"53 } \\
\text { For example, it is a complete non sequitur } \\
\text { to describe any demand for civil rights as } \\
\text { "true" or "false"; instead, any step in } \\
\text { broadening or limiting those rights can } \\
\text { only be "good" or "bad" in achieving } \\
\text { progress toward some socially- and } \\
\text { politically-defined goal, which itself might } \\
\text { change. }\end{array}$ & $\begin{array}{l}\text { 7. Every wicked problem is } \\
\text { essentially unique. } \\
\text { Every problem is embedded in a } \\
\text { particular set of complexly interacting } \\
\text { complex systems that is unlikely to be } \\
\text { duplicated elsewhere. Thus, "In the more } \\
\text { complex world of social policy planning, } \\
\text { every situation is likely to be one-of-a- } \\
\text { kind."554 }\end{array}$ \\
\hline $\begin{array}{l}\text { 4. There is no immediate and no } \\
\text { ultimate test of a solution to a wicked } \\
\text { problem. } \\
\text { "With wicked problems, ... the next day's } \\
\text { consequences of the solution may yield } \\
\text { utterly undesirable repercussions which } \\
\text { outweigh the intended advantages or the } \\
\text { advantages accomplished hitherto. In such } \\
\text { cases, one would have been better off if } \\
\text { the plan had never been carried out." } \\
\text { Again, social and political goals can } \\
\text { change, leading to re-evaluations of } \\
\text { solutions in the future. }\end{array}$ & $\begin{array}{l}\text { 8. Every wicked problem can be } \\
\text { considered to be a symptom of } \\
\text { another problem. } \\
\text { "Here lies a difficulty with } \\
\text { incrementalism, as well. This doctrine } \\
\text { advertises a policy of small steps, in the } \\
\text { hope of contributing systematically to } \\
\text { overall improvement. If, however, the } \\
\text { problem is attacked on too low a level } \\
\text { (an increment), then success of } \\
\text { resolution may result in making things } \\
\text { worse, because it may become more } \\
\text { difficult to deal with the higher } \\
\text { problems. Marginal improvement does } \\
\text { not guarantee overall improvement."56 } \\
\text { Rittel and Webber thus acknowledged } \\
\text { that scale, and how systems operating at }\end{array}$ \\
\hline
\end{tabular}

${ }^{53} \mathrm{Id}$. at $162-63$.

${ }^{54} \mathrm{Id}$. at 165.

${ }^{55} \mathrm{Id}$. at 163 .

${ }^{56} \mathrm{Id}$. at 165. 


\begin{tabular}{|c|c|}
\hline & $\begin{array}{l}\text { different scales interact, are important } \\
\text { components of wicked problems. }\end{array}$ \\
\hline $\begin{array}{l}\text { 6. Wicked problems do not have an } \\
\text { enumerable (or an exhaustively } \\
\text { describable) set of potential } \\
\text { solutions, nor is there a well- } \\
\text { described set of permissible } \\
\text { operations that may be incorporated } \\
\text { into the plan. } \\
\text { The types of solutions deemed acceptable, } \\
\text { or even possible, depend on cultural norms } \\
\text { and technological capability that } \\
\text { themselves change over time. "Which } \\
\text { strategies-or-moves are permissible in } \\
\text { dealing with crime in the streets, for } \\
\text { example, have been enumerated nowhere. } \\
\text { 'Anything goes,' or at least, any new idea } \\
\text { for a planning measure may become a } \\
\text { serious candidate for a re-solution ....." }\end{array}$ & $\begin{array}{l}\text { 9. The existence of a discrepancy } \\
\text { representing a wicked problem can } \\
\text { be explained in numerous ways. } \\
\text { The choice of explanation } \\
\text { determines the nature of the } \\
\text { problem's resolution. } \\
\text { Because of complexity, the world is not } \\
\text { entirely predictable or explainable. As a } \\
\text { result, the choice of world-view heuristic } \\
\text { (or cultural narrative) is critical to how } \\
\text { problems are perceived and addressed. } \\
\text { "That is to say, the choice of explanation } \\
\text { is arbitrary in the logical sense. In } \\
\text { actuality, attitudinal criteria guide the } \\
\text { choice. People choose those explanations } \\
\text { which are most plausible to them.." } 58\end{array}$ \\
\hline $\begin{array}{l}\text { 7. Every wicked problem is } \\
\text { essentially unique. } \\
\text { Cultural norms at different places and } \\
\text { times are simply too individualistic to } \\
\text { support "once size fits all" solutions. "The } \\
\text { conditions in a city constructing a subway } \\
\text { may look similar to the conditions in San } \\
\text { Francisco, say; but planners would be ill- } \\
\text { advised to transfer the San Francisco } \\
\text { solutions directly. Differences in } \\
\text { commuter habits or residential patterns } \\
\text { may far outweigh similarities in subway } \\
\text { layout, downtown layout and the rest."59 }\end{array}$ & \\
\hline $\begin{array}{l}\text { 10. The planner has no right to be } \\
\text { wrong. } \\
\text { "Experts" enjoy no particular privileges. } \\
\text { "In the world of planning and wicked } \\
\text { problems no such immunity is tolerated. . } \\
\text {. Planners are liable for the consequences } \\
\text { of the actions they generate; the effects can } \\
\text { matter a great deal to those people that are } \\
\text { touched by those actions." }{ }^{60} \text { Thus, because }\end{array}$ & \\
\hline
\end{tabular}

${ }^{57} \mathrm{Id}$. at 164.

${ }^{58} \mathrm{Id}$. at 166.

${ }^{59} \mathrm{Id}$. at 165.

${ }^{60} \mathrm{Id}$. at 167 . 
social norms can change, today's hero can

easily become tomorrow's scapegoat.

As a result of social capriciousness, problems become "wicked" because societies, unlike physics, have few if any universal and unchanging truths or goals. As Richard David Coyne observed, "Problem setting is a contingent, fraught, and sometimes consensual process for which there is no authoritative set of rules, criteria, or methods." 61 For example, concepts of "equity" and "justice" in the United States have been subject to almost continuously changing norms throughout the 20th and 21st centuries with respect to Native Americans, African-Americans, women, Hispanics, the LGBTQIA $+{ }^{62}$ community, and immigrants, among other groups.

Conversely (and acknowledging overlap because social systems are also complex systems), problems can be classified as wicked because social ecological problems partake of complex systems, where the whole is not only greater than the sum of its parts ${ }^{63}$ but also different from the sum of its parts and where complex adaptive systems inject elements of unpredictability and surprise. ${ }^{64}$ Before Part III more fully describes this ecological panarchy dynamism, however, the next section will close out the discussion of social capriciousness.

\section{The Increasingly Internalized Wickedness of Social Capriciousness}

As Rittel and Webber make clear from the beginning of "Dilemmas in a General Theory of Planning," social capriciousness is the dynamism at work in wicked problems that concerns them the most. Notably, they wrote during a cultural inflection point in the United States, ${ }^{65}$ where public attention was shifting from challenges that resonated in physics, chemistry, and engineering-World War II

${ }^{61}$ Richard Coyne, Wicked Problems Revisited, 26 Design Studies 26, 5e17, at 6 (2005), doi:10.1016/j.destud.2004.06.005

${ }^{62}$ The very fact that this acronym and the recognition of the different categories of sexuality behind it both keep expanding underscores the basic point. The expanded acronym stands for Lesbian, Gay, Bisexual, Transgender, Queer, Intersex, and Asexual; the "+" acknowledges that sexual identity is still expanding. LGBTQIA Resource Center, Glossary, https://lgbtqia.ucdavis.edu/educated/glossary (as updated Jan. 14, 2020).

${ }^{63}$ Donella H. Meadows, ThinkING IN Systems: A Primer 11-12 (2008).

${ }^{64} \mathrm{Id}$. at $86-87$.

${ }^{65}$ Notably, both 1968 and 1969 have been identified as watershed years for the United States, when "there was a sense of the country having just gone an enormous upheaval — a paradigm shift ...." Rob KirKPATRICK, 1969: The Year EVERYTHING Changed xv, xvi (2011). 
mobilization, ${ }^{66}$ "better living through chemistry," 67 the Cold War arms race, ${ }^{68}$ the space race and the first landing on the moon in $1969,{ }^{69}$ and the Vietnam War ${ }^{70}$ - to challenges that were social, political, and ecological in nature. Socially, as Rittel and Webber emphasize, the Civil Rights movement was prominent: the U.S. Supreme Court had decided Brown v. Board of Education ${ }^{71}$ in 1954, while Dr. Martin Luther King, Jr. delivered his "I Have a Dream . .." speech on August 28,

${ }^{66}$ Historians have proclaimed that "no war was as profoundly affected by science, math, and technology than WWII." David Mindell, The Science and Technology of World War II, https://www.ncpedia.org/anchor/science-and-technology-world (2009).

67 “The slogan, 'Better Living Through Chemistry,' was a popular variant of an advertising slogan by the DuPont Company that was used from the mid 1930s until the early 1980s." Sylvia R. Karasu, "It's Not Exactly Better Living Through Chemistry," Psychology Today, https:/www.psychologytoday.com/us/blog/the-gravity-weight/201308/its-not-exactly-better-

living-through-chemistry (Aug. 9, 2013).

68 "The Cold War period saw a dramatic expansion of state-funded science and technology research. Government and military patronage shaped Cold War technoscientific practices, imposing methods that were project oriented, team based, and subject to national-security restrictions. These changes affected not just the arms race and the space race but also research in agriculture, biomedicine, computer science, ecology, meteorology, and other fields." MIT Press, Naomi Orestes \& John Krige, eds., Science and Technology in the Global Cold War, https://mitpress.mit.edu/books/science-and-technology-global-cold-war (Oct. 2014).

${ }^{69}$ Referring to the 1969 moon landing as "the greatest engineering adventure ever taken," the American Society of Mechanical Engineers also notes that:

When President John F. Kennedy announced in 1961 his goal of sending a man to the moon, the United States had accomplished exactly 15 minutes of human spaceflight. America's space program had already absorbed several high-profile embarrassments and the Soviet Union was winning the "space race." Many thought that the president's incredibly challenging deadline of a decade was setting America up for another humbling loss.

America's political/Cold War fortunes were now in the hands of its top engineers. At the moment of Kennedy's announcement, the technology, infrastructure, hardware, and technical workforce needed to achieve this goal did not yet exist!

ASME, The Greatest Engineering Adventure Ever Taken, https://www.asme.org/topicsresources/content/the-greatest-engineering-adventure-ever-taken (Dec 28, 2010).

${ }^{70}$ David Biggs, for example, has referred to the Vietnam War as "the Chemical War." David Biggs, "Vietnam: The Chemical War," The New York Times, https://www.nytimes.com/2017/11/24/opinion/vietnam-the-chemical-war.html (Nov. 24, 2017). Alexis Madrigal, in turn, emphasizes the new role that computers and data crunching played in that conflict. Alexis C. Madrigal, "The Computer that Predicted the U.S. Would Win the Vietnam War," The Atlantic, https:/www.theatlantic.com/technology/archive/2017/10/the-computer-thatpredicted-the-us-would-win-the-vietnam-war/542046/ (Oct. 5, 2017).

${ }^{71}$ Brown v. Board of Education of Topeka, Shawnee County, Kansas, 347 U.S. 483, 495 (1954) (declaring "separate but equal" education of black children in public schools to violate the Fourteenth Amendment of the U.S. Constitution). 
1963, as part of the March on Washington ${ }^{72}$ and was assassinated less than five years later, on April 4, 1968. ${ }^{73}$ Recent political turmoil included President John F. Kennedy's assassination on November $22,1963,{ }^{74}$ student protests of the Vietnam War starting in October 1963 and "culminating most horribly in the May 1970 shooting of 13 Kent State University students by National Guardsmen," 75 Senator and presidential candidate Robert F. Kennedy's shooting on June 5, 1968, and death the next day, ${ }^{76}$ and the Watergate break-in in 1972, with growing investigations that led to the "Saturday Night massacres" in October 1973 and President Richard M. Nixon's resignation on August, 8, $1974 .{ }^{77}$ Finally, on the ecological front, Rachel Carson published Silent Spring in $1962,{ }^{78}$ challenging the assumption that "advances" in chemistry truly led to "better living," followed in 1970 by Congress's enactment of the National Environmental Policy Act ${ }^{79}$ (NEPA) and the Clean Air $\mathrm{Act}^{80}$ and the first Earth Day on April 22. ${ }^{81}$

As Table 1 emphasizes, many of Rittel's and Webber's characteristics of wicked problems are essentially acknowledgements that social systems and SESs, unlike the physical universe, have few if any universal and unchanging truths. The Civil Rights Movement and other social upheavals from the 1960s play prominently in Rittel's and Webber's contextualization of wicked problems, making it particularly clear that yesterday's social norms, such as slavery and segregation, will yield to tomorrow's - equality and integration. As Termeer et al. observed, "wicked problems are highly resistant to solutions because today's

72 The Martin Luther King, Jr. Research \& Education Inst., Stanford University, "I Have a Dream," Address Delivered at the March on Washington for Jobs and Freedom, https://kinginstitute.stanford.edu/king-papers/documents/i-have-dream-address-delivered-marchwashington-jobs-and-freedom (as viewed May 18, 2020).

${ }^{73}$ Editors, The Assassination of Martin Luther King, Jr., https://www.history.com/topics/blackhistory/martin-luther-king-jr-assassination (as updated Feb. 10, 2020).

74 The Day in History: November 22: President John F. Kennedy is assassinated, https://www.history.com/this-day-in-history/john-f-kennedy-assassinated (as updated Nov. 19, 2019).

75 "Protests and Backlash," The American https://www.pbs.org/wgbh/americanexperience/features/two-days-in-october-student-antiwarprotests-and-backlash/ (as viewed May 18, 2020).

${ }_{76}$ This Day in History: June 05: Bobby Kennedy is assassinated, https://www.history.com/thisday-in-history/bobby-kennedy-is-assassinated (as updated July 27, 2019).

${ }_{77}$ Editors, Watergate Scandal, https://www.history.com/topics/1970s/watergate (as updated Sept. $25,2019)$.

78 The Life and Legacy of Rachel Carson, Silent Spring, https://www.rachelcarson.org/SilentSpring.aspx (as viewed May 18, 2020).

${ }^{79}$ PuB. L. No. 91-190, 83 Stat. 852 (Jan. 1, 1970), codified as amended at 42 U.S.C. $\$ \S 4321-4370 \mathrm{~h}$. ${ }^{80}$ PuB. L. No. 91-604, 83 Stat. 1676 (Dec. 31, 1970), codified as amended at 42 U.S.C. $\S \S 7401-$ $7671 \mathrm{q}$.

81 America's The First Earth Day, http://www.americaslibrary.gov/jb/modern/jb modern earthday 1.html (as viewed May 18, 2020). 
problems emerge as a result of trying to understand and solve yesterday's problems." 82

However, rereading Rittel and Webber 50 years later also suggests that the social capriciousness component of wicked problems has itself, to a large extent, been internalized as a new cultural norm. For example, the authors' identification of "equity" as a new consideration that contributes to the wickedness of planning problems now reads as naïve and tips off the reader that the authors were caught in the transition away from the post-World War II era of assumed social uniformity and order. The entire final part of their article is a meditation on the new diversity, noting that " $[\mathrm{w}] \mathrm{e}$ have come to realize that the melting pot never worked for large numbers of immigrants to America, and that the unitary conception of 'The American Way of Life' is now giving way to a recognition that there are numerous ways of life that are also American." 83 They end their article by wondering: "In a setting in which a plurality of publics is politically pursuing a diversity of goals, how is the larger society to deal with its wicked problems in a planful way? How are goals to be set, when the valuative bases are so diverse? Surely a unitary conception of a unitary 'public welfare' is an anachronistic one." 84

This Article makes absolutely no claim that U.S. society has answered all of Rittel's and Webber's concerns or figured out how to make a diverse society functional, productive, and equitable over the long term. Notably, the U.S. Supreme Court continues to adjust how businesses and educational institutions may both acknowledge and resist diversity. ${ }^{85}$ At the same time, the gulf between the rich and the poor in the United States continues to widen, ${ }^{86}$ indicating that social and economic equity remain significant problems.

\footnotetext{
82 Termeer et al. supra note 2, at 681 .

${ }^{83}$ Rittel \& Webber, supra note 1, at 167-68.

${ }^{84} \mathrm{Id}$. at 168.

${ }^{85}$ E.g., Regents of the University of California v. Bakke, 438 U.S. 265, 319 (1977) (declaring a medical school's special admissions category for racial minorities unconstitutional); Johnson $\mathrm{v}$ Transportation Agency, 480 U.S. 616, 636-37 (1987) (upholding agency’s consideration of gender and affirmative action in promoting a female employee over a man with a higher test score); Masterpiece Cakeshop, Ltd. v. Colorado Civil Rights Comm'n, 138 S. Ct. 1719, 1731 (2018) (holding that the Colorado Civil Rights Commission violated its duty of religious neutrality in prosecuting a bakery for refusing to make a wedding cake for a homosexual couple on religious grounds).

${ }^{86}$ Lola Fadulu, "Study Shows Income Gap Between Rich and Poor Keeps Growing, with Deadly Effects," The New York Times, https://www.nytimes.com/2019/09/10/us/politics/gao-income-gaprich-poor.html (Sept. 10, 2019), based on Government Accountability Office, Income and Wealth Disparities Continue through Old Age (Aug. 2019), available at https://www.gao.gov/assets/710/700836.pdf.
} 
Nevertheless, this Article does make the far more modest claim that the fact of social and cultural diversity has become a social, cultural, and political given in the United States. The very fact that the issue of diversity continues to reach the Supreme Court is evidence of this internalization, and even the generally divisive terminology of "Red State" and "Blue State" simultaneously operates as an acceptance of diversity. In other words, while the United States still struggles to engage its various forms of diversity into a positive and productive national conversation, virtually no one expects this acknowledged diversity to disappear into a unitary culture.

Relatedly, the social capriciousness dynamic has also been absorbed into the United States' collective cultural narrative. This dynamism has been so thoroughly absorbed, in fact, that it hardly warrants the label "wicked" any longer. ${ }^{87}$ We expect society to change in ways that Rittel and Webber did not. We name generations of children ${ }^{88}$ and, more importantly, expect them to exhibit different behavioral and educational patterns from other generations throughout their lives, ${ }^{89}$ a conscious acknowledgement that norms, expectations, and to some extent even lived realities change continually. We are acutely aware of technology's rapid evolution and its continuous influence on cultural norms ${ }^{90}$ - and maybe even on how our brains work..$^{91}$ Indeed, knowledge of which communications technologies an individual has used, can use, and prefers to use can support a decent ballpark guess on how old that person is ${ }^{92}$ - as can an individual's expectations regarding

87 This cultural internalization is in effect a combination of the potential responses to wicked problems that Coyne laid out in 2005, particularly the pragmatic response. Coyne, supra note 54, at 7-10.

88 E.g., Kanasa, Boomers, Gen $X$, Gen $Y$, and Gen $Z$ Explained, https://www.kasasa.com/articles/generations/gen-X-gen-y-gen-Z (May 12, 2020).

89 E.g., Panopto, Are You Ready to Support 4 Generations of Learners?, https://www.panopto.com/blog/are-you-ready-to-support-4-generations-of-learners/ (Aug. 29, 2019); Susan El-Shamy, How to Design and Deliver Training for the New and EMERging GENERATIONS (2004).

${ }^{90}$ See, e.g., Mariela Combi, Cultures and Technology: An Analysis of Some of the Changes in Progress-Digital, Global and Local Culture, in Karol Jan Borowiecki, Neil Forbes, \& Antonella Fresa, eds., Cultural Heritage in a Changing World 3-15 (2016) (noting, for example, that " $[\mathrm{t}]$ oday cyberspace is a new realm of knowledge. Lévy uses the word cyberculture to mean the set of material and intellectual techniques, practices, attitudes, ways of thinking and values that are expressed and developed in cyberspace. Cyberculture is an enormous problem seeking solutions to constantly changing situations caused by technical developments and collective reactions.").

${ }^{91}$ The evidence to support this concern is still limited, however. Elena Pasquinelli, Are Digital Devices Altering Our Brains?, SCIENTIFIC AMERICAN, https://www.scientificamerican.com/article/are-digital-devices-altering-our-brains/) (Sept. 11, 2018).

${ }^{92}$ E.g., Notre Dame of Maryland University, The Evolution of Communication Across Generations, https://online.ndm.edu/news/communication/evolution-of-communication/ (Feb. 6, 2019); EUGĖNE Loos, Leslie Hadden, \& Enid Mante-MeiJer, eds., Generational Use of New Media (2012). 
which activities and information are or should be "private." 93 Technological evolution and generational differences merge in the recognition that the youngest inhabitants of the United States are "digital natives," while older generations are "digital immigrants," requiring the latter to face and adapt to this form of continual cultural change on a regular basis. ${ }^{94}$

In other words, some of Rittel's and Webber's "wicked problems" have morphed into, well, just life. From this perspective, Americans no longer even look for final solutions - a phrase, it is worth noting, that now comes with significant negative connotations ${ }^{95}$ - in many contexts. Society is organic and ecological, not mathematically engineered, and "social engineering" also has acquired fairly negative connotations. ${ }^{96}$ To view social problems as "wicked" because of increasing diversity and social capriciousness is simply to misapprehend the essential nature of the social realm.

\section{WHAT IS RESILIENCE THEORY AND WHAT DOES It HAVE TO DO WITH WiCKED PROBLEMS?}

${ }^{93}$ E.g., Steven J. Zansberg \& Janna K. Fischer, Privacy Expectations in On-Line Social Media-An Emerging Generational Divide?, 28:3 COMMUNICATIONS LAWYER 1 (Nov. 2011). Similar diversity occurs in Europe. Caroline Lancelot Miltgen \& Dominique Peyrat-Guillard, Cultural and generational influences on privacy concerns: a qualitative study in seven European countries, 23 EUR. J. INFORMATION SYS. 103-125 (Jan. 2019), https://doi.org/10.1057/ejis.2013.17.

${ }^{94}$ Digital natives "those born into an innate "new culture" of information technology and social media, "while the digital immigrants are old-world settlers, who have lived in the analogue age and immigrated to the digital world." Oliver Joy, CNN, What does it mean to be a digital native?, https://www.cnn.com/2012/12/04/business/digital-native-prensky/index.html (Dec. 8, 2012).

${ }^{95}$ Most importantly, “The term 'Final Solution of the Jewish Question' was a euphemism used by Nazi Germany's leaders. It referred to the mass murder of Europe's Jews. It brought an end to policies aimed at encouraging or forcing Jews to leave the German Reich and other parts of Europe. Those policies were replaced by systematic annihilation." U.S. Holocaust Memorial Museum, "Final Solution" Overview, https:/encyclopedia.ushmm.org/content/en/article/final-solutionoverview (ad edited Dec. 8, 2006). "Final Solution" then became the title of a 2004 movie "[s]et in Gujarat during the period Feb/March 2002 - July 2003" that graphically documents the changing face of right-wing politics in India through a study of the 2002 genocide of Moslems in Gujarat." Citizens for Justice and Peace, "Final Solution-Film by Rakesh Sharma, https://www.youtube.com/watch?v=P6yY8DFSnfw (Feb. 26, 2018).

${ }^{96}$ While "social engineering" means a variety of things to a variety of people, it became associated in the American mind with misguided attempts in Communist Russia and China to forcibly overhaul entire societies. E.g., David Ellerman, Scientism and Social Engineering: Lessons Learned from the Collapse of Communism and the Western Response, 1:1 SOCIAL SCIENCE TODAY 1-11 (2004). Most recently, in the cybersecurity context, "[s]ocial engineering is the art of manipulating people so they give up confidential information." Webroot, What Is Social Engineering?, https://www.webroot.com/us/en/resources/tips-articles/what-is-social-engineering (as viewed May 19, 2020). 
Part II suggested that some aspects of Rittel's and Webber's "wicked problems" - those emerging from increased consciousness of social and cultural diversity and the resulting dynamism of social capriciousness - might in fact seem less wicked today than they did in 1973. However, Rittel and Webber also tapped into an emerging appreciation of complex system dynamics-ecological panarchy - that continues to cause consternation in SES management. Thus, as Table 1 lays out, social problems are also wicked problems because communities and societies intersect and interact with a complex world that includes financial systems, ecosystems, legal systems, political systems, climate systems. Moreover, from the perspective of the 21 st century, wicked problems that partake of ecological panarchy tend to remain wicked.

Resilience theory both helps to explain why and offers insights for coping with such problems. Specifically, resilience theory provides a model of complex adaptive SESs that contrasts engineering resilience with ecological resilience, that accepts constant change as normal, and that assumes system interactions across a variety of geographic and temporal scales. ${ }^{97} \mathrm{By}$ accounting for the unpredictability of system perturbations and for system transformation, resilience theory helps to clarify why systems of systems make many kinds of social and social-ecological problems wicked. However, it also offers the hope that if society, governance, and law can better internalize this new model of reality, we might be able to better conceptualize and resolve certain kinds of wicked problems.

\section{A. Systems Thinking in Rittel and Webber}

While Rittel and Webber clearly appreciated the planning problems that social dynamism causes, they still clung to a view of nature and the environment as predictable, knowable, and orderly - the realm of the scientific manager and planning engineer. Thus, "As distinguished from problems in the natural sciences, which are definable and separable and may have solutions that are findable, the problems of governmental planning - and especially those of social or policy planning-are ill-defined; and they rely upon elusive political judgment for resolution."98 Notably, Rittel and Webber were writing at the same time that Congress was enacting the iconic federal environmental statutes- the National Environmental Policy Act (NEPA) ${ }^{99}$ and Clean Air Act ${ }^{100}$ in 1970, the Federal Water Pollution Control Act (Clean Water Act) ${ }^{101}$ in 1972, the Endangered Species

\footnotetext{
${ }^{97}$ See Angeler et al., supra note 7, at 225-26 (laying out the potential value of the panarchy model). ${ }^{98}$ Rittel \& Webber, supra note 1 , at 160 (emphasis added).

${ }^{99}$ Pub. L. No. 91-190, 83 Stat. 852 (Jan. 1, 1970), codified as amended at 42 U.S.C. $\$ \S 4321-4370$ h. ${ }^{100}$ PuB. L. No. 91-604, 84 Stat. 1676 (Dec. 31, 1970), codified as amended at 42 U.S.C. $\S \S 7401-$ $7671 \mathrm{q}$.

${ }^{101}$ Pub. L. No. 92-500, 86 Stat. 816 (Oct. 18, 1972), codified as amended at 33 U.S.C. §§ 12511388.
} 
Act $^{102}$ in 1973, the Solid Waste Disposal Act $^{103}$ and Fisheries Conservation and Management Act $^{104}$ in 1976, among others. Not coincidentally, those statutes also embodied - and to a large extent, still embody - the same mechanistic, Newtonian, "Balance of Nature" view of ecosystems that Rittel and Webber relied upon. ${ }^{105}$ It is this model of natural systems that resilience theory most emphatically replaces. ${ }^{106}$

At the same time, however, Rittel and Webber incorporated, at least in an embryonic form, systems theory, one of the underpinnings of resilience theory. Indeed, the recognition of the growing importance of systems thinking and the dynamism it adds is one of the more under-appreciated aspects of Rittel's and Webber's description of wicked problems. From the beginning of their 1973 discussion, they recognized that the professionals' description of reality was also changing, because:

The professionalized cognitive and occupational styles that were refined in the first half of this century, based in Newtonian mechanistic physics, are not readily adapted to contemporary conceptions of interacting open systems and to contemporary concerns with equity. A growing sensitivity to the waves of repercussions that ripple through such systemic networks and to the value consequences of those repercussions has generated the recent reexamination of received values and the recent search for national goals. ${ }^{107}$

Moreover, they were beginning to appreciate that these complex systems were themselves a source of unpredictability and surprise, noting that "[w]e are now sensitized to the waves of repercussions generated by a problem-solving action directed to any one node in the network, and we are no longer surprised to find it inducing problems of greater severity at some other node". ${ }^{108}$

These early incursions into systems thinking, moreover, underscored the dynamic nature of the reality that humans were trying to manage, as well as the difficulty of defining, let alone achieving, national goals. Thus, "Men in a wide

\footnotetext{
102 PuB. L. No. 93-205, 87 Stat. 884 (Dec. 28, 1973), codified as amended at 16 U.S.C. $\S \S 1531-$ 1540 .

103 PUB. L. No. 94-580, 90 Stat. 2796 (Oct. 21 1976), codified as amended at 42 U.S.C. §§ 6901$6992 \mathrm{k}$.

104 PuB. L. No. 94-265, 90 Stat. 331 (April 13, 1976), codified as amended at 16 U.S.C. $\S \S 1801-$

1882.

105 BENSON \& CRAIG, supra note 17 , at 29-31.

${ }^{106} I d$. at 48-49, 56-57.

${ }^{107}$ Rittel \& Webber, supra note 1, at 156 (emphasis added).

${ }^{108}$ Id. at 159 (emphasis added).
} 
array of fields were prompted to redefine the systems they dealt with in the syntax of verbs rather than nouns - to ask 'What do the systems do ?' rather than 'What are they made of ?"'109 As a result, efforts to define and locate problems within complex systems had themselves become problematic. ${ }^{110}$

Thus, while it is not the main point of their article, Rittel and Webber produced one of the first articles to acknowledge the governance issues that arise in a world of complex systems. Resilience theory can help to bridge the gap between this more complex reality and new approaches to governance. However, because resilience theory itself grew out of the new sciences of complexity, the next section will discuss those sciences first.

\section{B. Advancements in Complexity Theory and Systems Thinking Since 1973}

Complexity theory and systems thinking, both of which inform resilience theory, have come a long way since Rittel and Webber delineated wicked problems. Scientists - particularly biologists and ecologists but also computer scientists and information systems analysts - have increasingly recognized that both natural systems and human societies are complex systems - that is, systems where seemingly simple entities or components self-organize into intricate and interrelated networks of functions, products, and responses. ${ }^{111}$ Thus, "[i]n complex systems, many simple parts are irreducibly entwined, and the field of complexity is itself an entwining of many different fields." 112 Examples of complex systems include insect colonies, immune systems, brains, and economies ${ }^{113}$ —and, many would argue, law. ${ }^{114}$

Complexity scientists generally distinguish complex systems from complicated systems. ${ }^{115}$ As John Miller and Scott Page have explained:

\footnotetext{
${ }^{109} I d$. at 157 (emphasis in original).

${ }^{110} \mathrm{Id}$. at 159 .

${ }^{111}$ Melanie Mitchell, Complexity: A Guided Tour 4 (2009).

${ }^{112} \mathrm{Id}$.

${ }^{113} I d$. at 4-12.

${ }^{114}$ Gregory Todd Jones, Dynamical Jurisprudence: Law as a Complex System, 24 GA. STATE U. L. ReV. 873 (Summer 2008); J.B. Ruhl, Law's Complexity: A Primer, 24 GA. State U. L. REV. 885 (Summer 2008); Eric Kades, The Laws of Complexity and the Complexity of Laws: The Implications of Computational Complexity Theory for the Law, 49 RUTGERS L. REV. 403 (Winter 1997); J.B. Ruhl, The Fitness of Law: Using Complexity Theory to Describe the Evolution of Law and Society and Its Practical Meaning for Society, 49 VAnderbilt L. ReV. 1407 (Nov. 1996); J.B. Ruhl, Complexity Theory as a Paradigm for the Dynamical Law-and-Society System: A Wake-Up Call for Legal Reductionism and the Modern Administrative State, 45 DuKE L.J. 849 (March 1996).

115 John H. Miller \& Scott e. Page, Complex Adaptive Systems: An Introduction to Computational Models of Social Life 4 (2007).
} 
In a complicated world, the various schemes that make up the system maintain a degree of independence from one another. Thus, removing one such element (which reduces the level of complication) does not fundamentally alter the system's behavior apart from that which directly resulted from the piece that was removed. Complexity arises when the dependence among the elements become important. In such a systems, removing one such element destroys system behavior to an extent that goes well beyond what is embodied by the particular element that is removed. ${ }^{116}$

To dramatize the point: "A complex system dies when an element is removed, but complicated ones live on, albeit slightly compromised." 117

Complex systems have several distinguishing properties. First, they exhibit complex collective behavior - that it, individual components, following readily discernible rules of behavior, act collectively in vast numbers to "give rise to the complex, hard-to-predict, and changing patterns of behavior that fascinate us." 118 This property is often referred to as the self-organizing nature of complex systems, and the difficult-to-predict results are deemed emergent behaviors or properties. ${ }^{119}$

Second, complex systems "produce and use information and signals from both their internal and external environments." 120 As Neil Johnson has emphasized, the behavior of objects in a complex system "is affected by memory or 'feedback,", meaning "that something from the past affects something in the present, or that something going on at one location affects what is happening at another . . .."121 Thus, complex systems are linked systems, both temporally and spatially. Moreover, "the nature of this feedback can change with time."122

Finally, complex systems "adapt - that is, change their behavior to improve their chances of survival or success-through learning or evolutionary

${ }^{116} I d$. at 9.

${ }^{117} I d$.

118 Mitchell, supra note 111, at 12. See also Neil Johnson, Two's Company, Three Is COMPLEXITY 13, 15 (2007) (noting that a complex system "contains a collection of many interacting objects or 'agents," that it "exhibits emergent phenomena which are generally surprising, and may be extreme," and that "the emergent phenomena typically arise in the absence of any sort of 'invisible hand' or central controller").

119 Mitchell, supra note 111, at 13 (2009). See also Miller \& Page, supra note 115, at 9 ("The behavior of many complex systems emerges from the activities of lower-level components."); JOHNSON, supra note 118, at 5-9 (discussing emergent behavior and giving examples from a number of areas).

${ }^{120}$ MitChell, supra note 111, at 13.

${ }^{121}$ JOHNSON, supra note 118, at 14.

${ }^{122} \mathrm{Id}$. 
processes." 123 As a result, complex systems - sometimes more specifically referred to as "complex adaptive systems"124_are dynamic systems because "they change over time in some way." "25 The dynamic capabilities of complex systems, combined with their emergent behaviors, can give these systems a certain degree of resilience, or ability to cope with changes to and around the system. ${ }^{126}$ Specifically, these systems' emergent properties are "the result of a very powerful organizing force that can overcome a variety of changes to the lower-level components." 127

\section{From Complexity to Resilience Theory}

Acknowledging complexity sheds light on some reasons why wicked problems are wicked: they involve complex systems and interactions of complex systems that do not always respond as human managers want and intend them to. This new understanding of social-ecological reality demands that planners and managers work from a new framework or model in order to more effectively address wicked problems. Resilience theory provides one such model.

\section{Resilience Theory: Ecological versus Engineering Resilience}

The concept of resilience offers a new and potentially more productive orientation to wicked problems. Employing a complex systems approach, resilience theory emphasizes the qualities of ecological - as opposed to engineeringresilience. "Resilience" usually invokes what theorists call engineering resilience - that is, the ability of a person, thing, or system to resist a shock or disturbance in the first place or to bounce back to its former state. ${ }^{128}$ This definition "focuses on efficiency, constancy, and predictability - all attributes at the core of engineers' desires for fail-safe design." 129 Engineering resilience also embodies an expectation that natural systems have a preferred equilibrium balance to which they will return after a shock or disturbance and hence that preservation and restoration are and will always remain rational legal and policy goals. ${ }^{130}$ Engineering resilience, in other words, was one of the core properties of the world Rittel and

\footnotetext{
${ }^{123}$ MitChell, supra note 111, at 13. See also JOHNSON, supra note 118, at 14 ("The objects can adapt their strategies according to their history."

124 MitCHELL, supra note 111 , at 13.

${ }^{125} \mathrm{Id}$. at 15 .

${ }^{126}$ MiLler \& PAGE, supra note 115 , at 9.

${ }^{127} \mathrm{Id}$.

128 C.S. Holling, "Engineering Resilience versus Ecological Resilience," in NATIONAL ACADEMY of EngineEring, EngineERING Within ECOlOGICAL CONSTRAints 31, 33 (The National Academies Press 1996), https://doi.org/10.17226/4919, available at https://www.nap.edu/read/4919/chapter/4\#33.

${ }^{129}$ Id.

${ }^{130}$ BENSON \& CRAIG, supra note 17, at 30.
} 
Webber saw disappearing from their profession, replaced by the wicked problems that are not amenable to traditional professional (i.e., engineered) solutions.

In contrast, as defined by one of resilience theory's founders, the late C.S "Buzz" Holling, ecological "resilience determines the persistence of relationships within a system and is a measure of the ability of these systems to absorb change of state variable, driving variables, and parameters, and still persist." ${ }^{131}$ Ecological resilience describes the amount of change the system can undergo and still retain the same controls on function and structure. ${ }^{132}$ Ecologically resilient systems can absorb and cope with a certain amount of change without transforming into a qualitatively different state that is controlled by a different set of processes. ${ }^{133}$ This ability is reflects system's adaptive capacity - that is, the "capacity of actors, both individuals and groups, to respond to, create and shape variability and change in the state of the system." 134 Adaptive capacity reflects a system's flexibility and often reflects both functional diversity and redundancies within a system. ${ }^{135}$

However, resilience theory also acknowledges that complex systems do transform-undergo regime shifts-resulting in system processes that are so altered that the system now exists in a new system state. ${ }^{136}$ For example, in response to nutrient pollution, a freshwater lake can undergo a regime shift that transforms it from a clear, cold, trout-supporting ecosystem to a warm, algaedominated eutrophied system. ${ }^{137}$ Similarly, a social system dominated by a dictatorial political regime can reach a "tipping point" when levels of education and economic opportunity in a society prompt democratic regime changes. ${ }^{138}$

\footnotetext{
${ }^{131}$ C. S. Holling, Adaptive Environmental Assessment and Management 17 (1978).

132 BENSON \& CRAIG, supra note 17, at 57.

133 Stephen B. Carpenter, Brian Walker, J. Marty Anderies \& Nick Abel, From metaphor to measurement: Resilience of what to what? 4 ECOSYSTEMS 765, 766 (2001).

${ }^{134}$ F. Stuart Chapin, Carl Folke \& Gary P. Kofinas, A Framework for Understanding Change, in Principles of Ecosystem StewArdship 23, 26 (Stuart Chapin, Gary P. Kofinas \& Carl Folke, eds., 2009).

${ }^{135}$ Carl Folke, Johan Colding \& Fikret Berkes, Synthesis: Building Resilience for Adaptive Capacity in Social-Ecological systems, in NAVIGATING Social-ECOlOGiCAL Systems: Building RESILIENCE FOR COMPLEXITY AND CHANGE 352, 354 (2002).

${ }^{136}$ Holling, supra note 128 , at 31.

${ }^{137}$ Motomi Genkai-Katoi \& Stephen R. Carpenter, Eutrophication Due to Phosphorous Recycling in Relation to Lake Morphology, Temperature and Macrophytes, 86 ECOLOGY 210, 210 (2005).

${ }^{138}$ Recent political events in Egypt and Tunisia provide possible examples. See Robert L. Tignor, Can a New Generation Bring about Regime Change?, 43 InT'L J. OF MidDle EAST StUdiES 384, 384 (2011).
} 
Finally, ecological resilience also reflects how much external stabilization a system requires. ${ }^{139}$ To the extent to which there is a continuing need for external processes or support to maintain the system, it is less resilient. For example, ecosystems that require constant management interventions to maintain their current configurations are less resilient than those that flourish without human intervention.

\section{2. $\quad$ Panarchy: Adding Interactive Scales to Complex Systemic Change}

In 2002, Lance Gunderson and C.S. "Buzz” Holling described a four-phase infinity-loop cycle of change in ecological systems, which they termed the adaptive cycle. ${ }^{140}$ The four phases are rapid growth; conservation; release; and reorganization. ${ }^{141}$ A forest can provide a good example. A young forest proceeds through rapid growth to a mature conservation phase, when large trees tie up nutrients and limit further growth in the understory. A forest fire triggers the release phase, destroying structure and releasing nutrients, and the area will reorganize and begin to grow again. All else being equal, the area is likely to regenerate a new forest that looked a lot like the last one-but maybe not.

The chaos and potential unpredictability of the release and reorganization phases of the adaptive cycle are one source of dynamism within resilience theory. In addition, adaptive cycles operating at different temporal and geographic scales interact with each other, a model of system complexity that Gunderson and Holling termed "panarchy." 142 Panarchy incorporates a systems perspective on natural resources, ${ }^{143}$ reflecting the fact that ecological and social-ecological systems are complex adaptive systems. The panarchical interactions of nested adaptive cycles thus reflect the very real complexity and unpredictability to natural systems, revealing an avoidable element of management chaos that Rittel and Webber lamented. ${ }^{144}$

This model of ecological and social-ecological panarchy offers two main insights into the nature of wicked problems. First, panarchy means that any given approach to a particular problem will not always generate the same response,

\footnotetext{
139 Carl Folke, F. Stuart Chapin \& Per Olsson, Transformations in Ecosystem Stewardship, in Principles of Ecosystem Stewardship 14 (Stuart Chapin, Gary P. Kofinas \& Carl Folke, eds., 2009).

140 WALKer \& SAlt, supra note 19, at 75-78; LANCE Gunderson \& C.S. Holling, PanARChy: Understanding TRANSFORMATIONS IN HumAN AND NATURAL Systems 33-35 (Island Press 2002).

141 Gunderson \& Holling, supra note 140, at 33-35.

${ }^{142} \mathrm{Id}$. at 72-76.

143 WALKER \& SALT, supra note 19 , at 31.

144 BENSON \& CRAIG, supra note 17, at 61-63.
} 
requiring that managers and governance systems be flexible and nimble in generating solutions over time. Second, panarchical interactions among different scales of systems, combined with the feedback loops and nonlinear responses that characterize complex adaptive systems, mean that the conditions in which wicked problems operate-and potentially some of the facets of the wicked problem itself-are themselves changing over time. As such, the managers pursuing solutions must themselves adapt over time. Thus, as was true for social capriciousness, wicked problems that participate in panarchical systems - as most do-are not amenable to once-and-done solutions. Indeed, their "solution" may not be an answer at all, but rather a continual adaptive process.

\section{The Wicked Problem of Climate Change Viewed through the Lens of Resilience Theory}

Climate change is a leading contender for "world's worst wicked problem." Indeed, many scholars have labeled climate change a "super-wicked problem."145 According to Levin et al., "Super wicked problems comprise four key features: time is running out; those who cause the problem also seek to find a solution; the central authority needed to address them is weak or non-existent; and irrational discounting occurs that pushes responses into the future."146 In other words, super wicked problems like climate change suffer from two challenges in addition to social capriciousness and ecological panarchy (which extends to "time is running out," the result of complex systemic feedback loops): they occupy governance gaps ${ }^{147}$ and they trip human cognitive psychology in highly unproductive ways. ${ }^{148}$

While not a panacea, resilience theory helps to model the complex dynamics of climate change, allowing it to both support a new cultural narrative ${ }^{149}$ and. As Part IV will explore in more detail, allow a variety of new approaches to governance

145 Lazarus, supra note 7, at 1159; Kelly Levin, Benjamin Cashore, Steven Bernstein \& Graeme Auld, Overcoming the tragedy of super wicked problems: constraining our future selves to ameliorate global climate change, 45:2 POLICY SCIENCES 123, 124 (2012), https://www.jstor.org/stable/41486859.

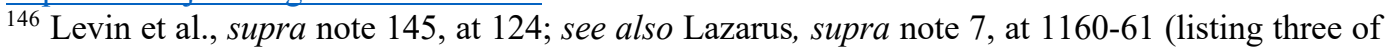
these features).

${ }^{147}$ Levin et al., supra note 145, at 124 (noting that "our governance institutions, and the policies they generate (or fail to generate), largely response to short-term time horizons even when the catastrophic implications of doing so are far greater than any real or perceived benefits of inaction"); Lazarus, supra note 7, at 1161-73 (describing carbon dioxide's behavior and the legal mismatches that arise).

${ }^{148}$ Lazarus, supra note 7, at 1173-79; see also generally GEORGE MARSHALL, DON'T EVEN THINK About It: Why Our Brains ARe Hard-Wired to Ignore Climate Change (2014) (providing an extensive exegesis of the behavioral psychology problems that hamper effective responses to climate change).

${ }^{149}$ BENSON \& CRAIG, supra note 17 , at 48-78, 135-159. 
and law to emerge. With respect to climate change in particular, resilience theory helps to model the multi-scalar dynamics of climate change-specifically, because carbon participates in adaptive cycles operating at all scales, a panarchical conception of the planet readily explains how humans burning fossil fuels could perturb large-scale systems like the climate and the planetary carbon cycle out of their relatively stable conservation phases.

The Earth's carbon system is in fact an array of different components that operate on a variety of time scales. ${ }^{150}$ Fast components of this cycle move carbon biologically through life forms and ecosystems, while the slowest components take millions to tens of millions of years to cycle carbon through rocks and the planetary crust and then into volcanoes, which return the carbon to the atmosphere as carbon dioxide. ${ }^{151}$ The ocean's gas exchange with the atmosphere at the ocean's surface and its absorption of carbon dioxide is one of the faster elements of the slow carbon cycle. ${ }^{152}$ Rocks, the ocean, and the atmosphere are all carbon reservoirs, balancing the location and reactivity of carbon on Earth at any given time. Importantly, removing carbon (including carbon dioxide) from one reservoir simply shifts it to a different reservoir. Viewed from this global earth science perspective, humans using fossil fuels actively disrupt the normal balance of carbon cycle components, accelerating the return of carbon to the atmosphere from oil and coal deposits through the very fast processes of mining, drilling, and burning, compared to the very slow geological processes that would normally govern those deposits. ${ }^{153}$

Thus, when humans burn fossil fuels and otherwise emit carbon dioxide and methane, they perturb adaptive cycles at multiple temporal and spatial scales, the responses of which similarly vary in scale. The most immediate and local result of the Industrial Revolution's accelerated use of fossil fuels was air pollution. "Killer fog" events in industrialized cities such as Donora, Pennsylvania (1948), ${ }^{154}$ and London, England (1952), ${ }^{155}$ epitomized the disruption of local and short-term adaptive cycles governing air quality and led directly to air quality legislation-in the United States, the Clean Air Act of $1970 .{ }^{156}$ Responses to the COVID-19

\footnotetext{
${ }^{150}$ Holli Riebeek, The Carbon Cycle, NAt'L Aeronautics \& SPACE Admin. EARTH OBSERVATORY (June 16, 2011), http://earthobservatory.nasa.gov/Features/CarbonCycle/.

${ }^{151} \mathrm{Id}$.

${ }^{152} I d$.

${ }^{153}$ See Peter M. Cox et al., Acceleration of Global Warming Due to Carbon-Cycle Feedbacks in a Coupled Climate Model, 408 NATURE 184, 184-87 (2000) (explaining this acceleration).

${ }^{154}$ Lorraine Boissoneault, The Deadly Donora Smog of 1948 Spurred Environmental ProtectionBut Have We Forgotten the Lesson?, SMITHSONIAN MAGAZINE, https://www.smithsonianmag.com/history/deadly-donora-smog-1948-spurred-environmentalprotection-have-we-forgotten-lesson-180970533/ (Oct. 28, 2018).

${ }^{155}$ Christopher Klein, The Great Smog of 1952, https://www.history.com/news/the-killer-fog-thatblanketed-london-60-years-ago (as updated Aug. 22, 2018).

15642 U.S.C. $\S \S 7401-7679 q$.
} 
pandemic incidentally demonstrated how fast clean air can return in response to reduced car and airplane traffic. ${ }^{157}$ In contrast, climate change reflects increased atmospheric concentrations of carbon dioxide (and other greenhouse gases) operating at a global scale to disrupt the adaptive cycle of the planetary climate, disruptions that will take centuries to return to normal levels even if all carbon dioxide emissions cease tomorrow. ${ }^{158}$ The global climate adaptive cycle, notably, has been in a relatively stable conservation phase for the entire roughly 12,000 years of human civilization. ${ }^{159}$ Because the climate is a higher-order adaptive cycle, its perturbations, releases, and reorganizations affect all of the adaptive cycles below it - that is, all of the SESs humans live within, as the Intergovernmental Panel on Climate Change and a variety of other researchers document on an increasingly regular basis. ${ }^{160}$ Finally, the ocean absorbs carbon dioxide as part of the millennial-scale global carbon cycle, resulting in marine $\mathrm{pH}$ levels dropping at a rate unseen for 50 million years, with significant follow-on changes to the chemical and biological functioning of the ocean. ${ }^{161}$

This is a lot of change, but "panarchy theory accounts for feedbacks that can stabilize or destabilize system configurations due to cross-scale interactions." ${ }^{162}$ Resilience theory and panarchy also help to model the more subtle workings of climate change. Angeler et al. provide one extended example for methane production in lakes. "[M]ethane emission in a single lake . . . contributes to the global carbon balance in the atmosphere" while at the same time "further atmospheric carbon enrichment boosts local emission of methane from lakes."163 Over the course of a year, moreover, both seasonal adaptive cycling and large-scale weather patterns like the El Niño Southern Oscillation influence the lake's methane production, demonstrating that "dynamic patterns are linked across scales (from local, to regional, to global), making patterns at one scale dependent on those at

${ }^{157}$ Beth Gardiner, Pollution made COVID-19 worse. Now, lockdowns are clearing the air, National Geographic, https:/www.nationalgeographic.com/science/2020/04/pollution-made-the-pandemicworse-but-lockdowns-clean-the-sky/ (April 8, 2020).

158 Intergovernmental Panel on Climate Change, Climate Change 2014: Synthesis REPORT 16 (2014) ("A large fraction of anthropogenic climate change resulting from $\mathrm{CO}_{2}$ emissions is irreversible on a multi-century to millennial timescale, except in the case of a large net removal of $\mathrm{CO}_{2}$ from the atmosphere over a sustained period.")

159 James E. Hansen \& Makiko Sato, Earth's Climate History: Implications for Tomorrow, https://www.giss.nasa.gov/research/briefs/hansen 15/ (July 2011) ("Civilization developed during the Holocene, the interglacial period of the past 10,000 years during which global temperature and sea level have been unusually stable.").

160 Intergovernmental Panel on Climate Change, Climate Change 2014: Synthesis REPORT 12-15 (2014).

${ }^{161}$ Richard A. Kerr, Ocean Acidification Unprecedented, Unsettling, 328 SCIENCE 1500, 1500-01 (2010) (emphasizing the speed of current ocean acidification).

${ }^{162}$ Angeler et al., supra note 7, at 226.

${ }^{163} \mathrm{Id}$. 
other scales."164 Thus, through adaptive cycles and panarchy, resilience theory offers a model of reality in which climate change "makes sense"-a reality in which puny humans acting locally can in fact disrupt the entire planet. While of course no single model or heuristic can overcome all of the psychological challenges to effective climate change governance and action, resilience theory nevertheless offers a helpful adjustment to prior cultural narratives. ${ }^{165}$

\section{HOW DOES RESILIENCE THEORY HELP US TO COPE WITH WICKED Problems?}

\section{A. Resilience Theory Teaches Us Social-Ecological Systems Are Always Changing and Can Act or Respond in Unpredictable Ways, Normalizing Wicked Problems}

Politicians and legal systems have long treated the environmentlandscapes and public lands, ecosystems, watersheds-as complicated systems capable of being managed for individual components, when in fact they have always been complex adaptive systems. This worldview-Rittel's and Webber's world of the Engineer - may make wicked problems seem worse than they actually are: problems are "wicked" in part because they are an affront to settled expectations of how reality will function, making it all the more difficult to conceptualize how to solve them.

Thus, as Angeler et al. have observed from the science side of wicked problems, "Coping with and managing the challenges at hand requires integrative models that account for this complexity and complement traditional approaches for dealing with change and its associated risks." "166 Resilience theory offers a different model of reality, one in which complex or "wicked" problems can become expected or normalized. ${ }^{167}$ While resilience theory emphasizes that no particular problem is completely predictable, it does also lead us to expect that such problems will arise over time. As John Miller and Scott Page have emphasized, "At the most basic level, the field of complex systems challenges the notion that by perfectly understanding the behavior of each component part a system we can then understand the system as a whole." 168 Or, as Neil Johnson has more colorfully summarized, complexity theory "represents a slap in the face for traditional

\footnotetext{
${ }^{164} \mathrm{Id}$.

165 BENSON \& CRAIG, supra note 17 , at 7-21.

166 Angeler et al., supra note 7, at 225.

167 See id. at 226 ("Resilience thinking, which focuses on the ability of systems to prepare for, absorb and recover from an adverse event and crucially adapt to new conditions . . . offers a new way of living with these risks" (citations omitted)).

168 MiLler \& PAGE, supra note 6, at 3.
} 
reductionist approaches to understanding the world." 169 This mental, social, and governance correction to the Engineer's view of the world is in itself a step forward in dealing with wicked problems.

\section{B. Resilience Theory Helps Us to Learn to Live with the Trickster}

Rittel and Webber share one notable mental construct with resilience theorists: they felt it necessary to reach for a trickster figure to describe their new reality. Thus, they used 'the term 'wicked' in a meaning akin to that of 'malignant' (in contrast to 'benign') or 'vicious' (like a circle) or 'tricky' (like a leprechaun) or 'aggressive' (like a lion, in contrast to the docility of a lamb)." ${ }^{170}$ Almost 20 years later, Lance Gunderson and Buzz Holling invoked the Greek trickster god Pan to coin their term "panarchy" within resilience theory. ${ }^{171}$ As J.B. Ruhl has noted, "They coined the name 'panarchy' . . . after the flautist and god of nature, Pan, to position it 'as an antithesis to the word hierarcy' and to capture its 'cross-scale, interdisciplinary, and dynamic nature' ...."172

Notably, neither Rittel and Webber nor Gunderson and Holling were completely comfortable with the idea that reality is a trickster, a fact most obvious in Rittel's and Webber's rhetorical equating of tricky leprechauns to things "malicious," "vicious," and "aggressive." There is a good anthropological basis for that discomfort: Tricksters are agents of chaos and change, forces that disrupt normal expectations and sometimes violate important cultural or sacred boundaries. ${ }^{173}$ Nevertheless, trickster tales are often funny (Coyote, Raven, Brer Rabbit) rather than scary - the Norse Loki notwithstanding. More importantly, like ecological resilience, "the trickster is generally neither good nor evil; he is amoral," "simply a facet of reality, not a moral theory or prescription." 174

Resilience theory, resonating through the cultural narratives of the trickster, can help to confer this more helpful and realistic amorality to Rittel's and Webber's "wicked" problems: The fact that the world does not behave, always, as we expect it to should be the occasion for changing human expectations rather than for redoubling our efforts to control every facet of the complex and scaled system of systems that constitute our reality. As Thomas and Patricia Thornton have noted, tricksters represent "an alternative heuristics circulating in many indigenous

\footnotetext{
169 JOHNSON, supra note 118 , at 17.

${ }^{170}$ Rittel and Webber, supra note 1, at 160.

${ }^{171}$ Gunderson \& Holling, supra note 22, at 21.

172 J.B. Ruhl, Panarchy and the Law, 17(3) ECOLOGY \& SocIETY, art. 31, at 1 (2012) (quoting GUNDERSON \& HOLLING, supra note 140, at 5, 21).

173 “Tricksters," Myths Encyclopedia, http://www.mythencyclopedia.com/Tr-Wa/Tricksters.html (as viewed Jan. 17, 2016).

${ }^{174}$ BENSON \& CRAIG, supra note 17, at 51 (citations omitted).
} 
communities that are instead shaped by the shared understanding that humans are but a small part of a relational universe that cannot be fully cognized, much less managed, by any one species." 175 Resilience theory supplies the scientific model of ecological and social-ecological reality to match this cultural heuristic. ${ }^{176}$

In trickster tales, "as humans interact with the trickster and his disruptions, they learn to adapt to change to accommodate the new realities that the trickster brings, helping to ensure their own survival." 177 Tricksters are thus often powerful cultural narratives for dealing with a world of continual change that "place humans in a different relationship to ecological change than the dominant US narratives do-humans are neither controlling engineers or victims of natural forces but rather components of a complex system who have a real but bounded ability to deal with its changes." 178

This "resilient trickster" view of the world, and humans' role within it, can helpfully reset planners' and managers' expectations for wicked problems, recasting them as realities to cope with rather than as evil intrusions into human goals that need to be eliminated. For example, in the American West, climate change and drought can occasion tremendous legal battles among those seeking to maintain the status $q u o^{179}$ _ but they can also lead to renegotiations, assisted transformation of social-ecological systems, and even the removal and reconfiguration of massive infrastructure like dams. ${ }^{180}$

\section{Resilience Theory Offers a Framework for Improving the Law and Governance Necessary to Address Wicked Problems}

Governance institutions ${ }^{181}$ are critical to dealing with wicked problems, but_-as Rittel and Webber repeatedly pointed out-governance processes and

\footnotetext{
175 Thomas E. Thornton \& Patricia M. Thornton, The Mutable, the Mythical, and the Managerial: Raven Narratives and the Anthropocene, 6:1 ENVIRONMENT \& SOCIETY 66, 68 (2015).

176 BENSON \& R CRAIG, supra note 17, at 51 (citations omitted).

${ }^{177} I d$. (citations omitted).

${ }^{178} I d$.

179 Holly Doremus \& A. Dan Tarlock, Water War in the Klamath Basin: Macho Law, Combat Biology, AND DirTy Politics 112-144 (2008).

${ }_{180}$ Brian C. Chaffin, Robin Kundis Craig, \& Hannah C. Gosnell, Resilience, Adaptation, and Transformation in the Klamath River Basin Social-Ecological System, 51 IDAHO L. REV. 157, 18692 (2014).

181 "Governance" "refers to the means . . . through which collective goals are chosen, decisions are made, and action is taken to achieve the chosen goals," while "environmental governance" denotes the more specific governance mechanisms "related to society's interactions with natural systems." Barbara A. Cosens, Lance Gunderson, \& Brian C. Chaffin, Introduction to the Special Feature Practicing Panarchy: Assessing legal flexibility, ecological resilience, and adaptive governance in regional water systems experiencing rapid environmental change, 23 ECOLOGY \& SOCIETY art. 4,
} 
goals do not always mesh well with the nature of wicked problems. Thus, as Termeer et al. have argued, attention must turn to "how governance systems may be enabled for dealing with wicked problems. Conventional methods of problem solving do not seem to work and most conventional governance systems are poorly equipped for alternative strategies." 182

One indication that resilience theory can help to improve the governance of wicked problems is the number of scholars who have latched on to resilience theory as the framework that can support the governance necessary to cope with wicked problems generally or, more often, the specific wicked problem of climate change. This section highlights three sets of these scholarly endeavors to illustrate how resilience thinking can help to both ground and shape governance for wicked problems.

\section{Four Governance Capabilities for Dealing with Wicked Problems}

Termeer et al. have argued "that it takes a set of four capabilities for governance actors (and systems) to deal wisely with wicked problems, that is, the capabilities of reflexivity, resilience, responsiveness, and revitalization."183 Importantly, like Angeler et al., Termeer et al. find resilience theory immediately relevant to wicked problems, although this time from the governance side. Indeed, their "resilience" capability for dealing with wicked problems derives directly from resilience theory. ${ }^{184}$

Specifically, a resilience capability allows the governance system "to adapt to a constantly changing flow of problem definitions, solutions, and context conditions." "185 This adaptability is necessary because wicked problems are panarchical: "Because of their multidimensional and interconnected characteristics, wicked problems involve causes and effects at multiple scales of time and space. These waves of consequences cannot be predicted beforehand." 186 Without this

at 3 (2018), https://doi.org/10.5751/ES-09524-230104. See also Brian C. Chaffin, Hannah Gosnell, $\&$ Barbara A. Cosens, A decade of adaptive governance scholarship: Synthesis and future directions, 19 ECOLOGY \& SOCIETY art. 56, at 1 (2014), http://dx.doi.org/10.5751/ES-06824-190356 ("Broadly, environmental governance can be thought of as a 'set of regulatory processes, mechanisms and organizations through which political actors influence environmental actions and outcomes' ... . In short, environmental governance is the system of institutions, including rules, laws, regulations, policies, and social norms, and organizations involved in governing environmental resource use and/or protection, and there are a variety of different approaches." (citations omitted)).

182 Termeer et al., supra note 2, at 681 .

${ }^{183} \mathrm{Id}$. at 682 .

${ }^{184}$ See id. at 689 (citing prominent resilience theory scholars).

${ }^{185} \mathrm{Id}$. at 684 .

${ }^{186} \mathrm{Id}$. 
resilience capability, moreover, a governance system "may erode to the point that a small disturbance provokes a failure to keep fulfilling basic functions." 187 To enable this resilience capability, Termeer et al. adopt the governance system features that enable "a culture that tolerates continuous processes of change in unpredictable directions" 188 from Carl Folke et al.'s 2005 resilience theory article. ${ }^{189}$ These features include bridging organizations; "flexible legislation that allows for tailor-made solutions flexible legislation that allows for experiments and tailor-made solutions, decentralizing decision-making authority, and room for selfgovernance" ${ }^{190}$; and redundancy in the governance system. ${ }^{191}$

Resilience thinking also influences Termeer et al.'s other three governance capabilities. Reflexivity, for example, directly responds to the diversity aspect of wicked problems and "is essential to deal with the variety of possible perspectives on wicked problems and to prevent tunnel vision." ${ }^{192}$ Notably, to enable reflexivity in governance, Termeer et al. advocate a kind of cyclical social regime shifting to embed reflexivity in governance, where people are "frequently going back and forth between reflexive and day-to-day activities . . .."193 The responsiveness capability, in turn, allows governance systems "to react to changing demands while striking a balance between different public values." 194 However, ignoring the panarchical nature of wicked problems will only lead to trouble; instead, policymakers must embrace the difficult task of balancing social stability and flexibility in light of changing social-ecological systems. ${ }^{195}$ Finally, the revitalization capability "is

\footnotetext{
${ }^{187} I d$. at 685 .

${ }^{188} I d$. at $690-91$.

189 Carl Folke, Thomas Hahn, Per Olsson \& Jon Norberg, J., Adaptive governance of social ecological systems, 30 ANNUAL REV. OF ENV'T \& RESOURCES 441-473 (2005), doi: 10.1146/annurev.energy.30.050504.144511.

${ }^{190}$ See also Ahjond Garmestani, J. B. Ruhl, Brian C. Chaffin, Robin K. Craig, Helena F. M. W. van Rijswick, David G. Angeler, Carl Folke, Lance Gunderson, Dirac Twidwell, \& Craig R. Allen, Untapped capacity for resilience in environmental law, 116 PROC. NATL. ACADEMY SCIENCES (PNAS) 19,899-19,904 (Oct. 1, 2019), www.pnas.org/cgi/doi/10.1073/pnas.1906247116 (arguing that there is sufficient flexibility in existing environmental laws to begin making progress on climate change).

${ }^{191}$ Termeer et al., supra note 2, at 690-91 (citing Folke et al., supra note 189, at 441-473).

${ }^{192} I d$. at 684 .

${ }^{193} I d$. at 688 .

${ }^{194} I d$.

${ }^{195} I d$. at 684, 685. See also generally Robin Kundis Craig, Ahjond S. Garmestani, Craig R. Allen, Craig Anthony (Tony) Arnold, Hannah Birgé, Daniel A. DeCaro, Alexander K. Fremier, Hannah Gosnell, \& Edella Schlager, Balancing stability and flexibility in adaptive governance: an analysis of tools available in U.S. environmental law, 22 ECOLOGY \& SOCIETY, art. 3 (2017), https://doi.org/10.5751/ES-08983-220203 (discussing the importance of this balance if effective and legitimate adaptive governance); Andreas Duit \& Victor Galaz, Governance and complexity: Emerging issues for governance theory, 21: GOVERNANCE: AN INTERNATIONAL JOURNAL OF POLICY, ADMINISTRATION, AND INSTITUTIONS 311-335 (2008) (creating a typology of governance systems based on their adaptive capacities).
} 
necessary to unblock unproductive patterns in the governance process."196 More specifically, "Revitalization refers to the capability of actors in a governance system to recognize and unblock counterproductive patterns in policy processes, and thus to reanimate actors and to enhance processes of innovation needed to cope with wicked problems." 197 In Termeer et al.'s conception, therefore, revitalization is a governance system's version of the release phase in an adaptive cycle-the ability to break out of old patterns and to reorganize to more effectively respond to wicked problems.

\section{Adaptive Governance}

Thomas Dietz, Elinor Ostrom, and Paul C. Stern are generally credited with coining the terming "adaptive governance" in 2003 to describe a new kind of environmental governance, ${ }^{198}$ although the concept existed earlier. ${ }^{199}$ If resilience theory is a scientific model of continual change in complex ecological and socialecological systems, then adaptive governance is the legal and policy response to that same reality - "environmental governance that allows emergence of collective action capable of facilitating adaptation to change and surprise as well as the capacity to itself evolve."200

While adaptive governance by definition cannot be mandated, ${ }^{201}$ societies can enhance the chances that adaptive governance will both emerge and take root as the new governance system. ${ }^{202}$ As Termeer et al. noted, Folke et al. provided a fairly comprehensive examination of the social dimensions of adaptive

\footnotetext{
196 Termeer et al., supra note 2, at 686.

${ }^{197} \mathrm{Id}$.

198 Thomas Dietz, Elinor Ostrom, \& Paul C. Stern, The struggle to govern the commons, 302 SCIENCE 1907, 1908 (2003), http://dx.doi.org/10.1126/science.1091015.

${ }^{199}$ Chaffin, Gosnell, \& Cosens, supra note 181, at 3 tbl. 1.

${ }^{200}$ Cosens, Gunderson, \& Chaffin, supra note 181, at 3. See also Chaffin, Gosnell, \& Cosens, supra note 181, at 1 ("Given the uncertainties associated with global environmental change, including climate change and massive shifts in land use, environmental governance systems going forward must be highly adaptive. Governance systems, particularly those of top-down, state-based orientation, rarely match the relevant scale of ecological complexity, especially in the face of rapid environmental change ...." (citations omitted)), 4-5 (situating adaptive governance within resilience theory scholarship), 5 (noting that adaptive governance "is unanimously viewed as a system of environmental governance with the potential to mediate the complexity and uncertainty inherent in SESs [social-ecological systems] ....").

${ }^{201}$ Chaffin, Gosnell, \& Cosens, supra note 152, at 8 (discussing adaptive governance as an emergent institution and concluding "that the social components of a SES must be adequately 'prepared' before transformation can take place").

${ }^{202}$ Barbara A. Cosens, Robin K. Craig, Shanna Lee Hirsch, Craig Anthony (Tony) Arnold, Melinda Harm Benson, Daniel A. DeCaro, Ahjond S. Garmestani, Hannah Gosnell, J.B. Ruhl, \& Edella Schlager, The role of law in adaptive governance, 22 ECOLOGY \& SOCIETY art. 30 (2017), https://doi.org/10.5751/ES-08731-220130.
} 
governance. ${ }^{203}$ Moving into law, Cosens et al. have offered a set of guidelines for assessing whether a particular governance regime is primed for adaptive governance. ${ }^{204}$ First, the structure of law of law and governance must be polycentric, integrative, and persistent. ${ }^{205}$ In terms of capacity, the governance system must have both adaptive capacity, the authority and willingness to respond to change, and participatory capacity, meaning that the relevant stakeholders have both the legal right and sufficient resources to participate in decisionmaking. ${ }^{206}$ Finally, the governance system must have the legal processes in place to ensure legitimacy, procedural justice, and dispute resolution while at the same time achieving a problem-solving approach, the ability to balance stability and flexibility, and the capacity to reflect upon and learn from prior decisions. ${ }^{207}$ This collection of factors ensures that adaptive governance remains "good governance"-i.e., that the relevant governance system can adapt to a changing social-ecological system through methods and decisions that will be viewed as legitimate, inclusive, and imposing only the necessary amounts and kinds of social and economic disruption. ${ }^{208}$

Even this quick summary is sufficient to reveal substantial similarities between the characteristics of a legal system that can support adaptive governance and Termeer et al.'s four governance capacities that enable societies to more effective deal with wicked problems. Moreover, adaptive governance scholarship - from whatever discipline - tends to focus on the wicked problem of climate change. ${ }^{209}$ This convergence again suggests that resilience theory's model of a continually and complexly changing reality could aid governance systems in both conceptualizing and more productively addressing wicked problems.

\footnotetext{
${ }^{203}$ Folke et al., supra note 189 , at 445-47.

${ }^{204}$ Cosens et al., supra note 202, at 2 tbl. 1.

${ }^{205} \mathrm{Id}$.

${ }^{206} \mathrm{Id}$.

${ }^{207} \mathrm{Id}$.

208 Id. at 3.

${ }^{209}$ E.g., Barbara Cosens, Lance Gunderson \& Brian Chaffin, The Adaptive Water Governance Project: Assessing Law, Resilience, and Governance in Regional Socio-Ecological Water Systems Facing a Changing Climate, 51 IDAHO L. REV. 2-28 (2014-2015); Robin Bronen \& F. Stuart Chapin III, Adaptive governance and institutional strategies for climate-induced community relocations in Alaska, 110 PROC. NATL. ACAD. SCIENCES (PNAS) 9320-9325 (June 4, 2013), https://doi.org/10.1073/pnas.1210508110; Jeroen Rijke, Rebekah Brown, Chris Zevenbergen, Richard Ashley, Megan Farrelly, Peter Morison, \& Sebastiaan van Herk, Fit-forpurpose governance: A framework to make adaptive governance operational, 22 ENVTL. SCI. \& POL'Y 73-84 (Oct. 2012); RonAlD H. BRunNER \& AmANDA H. LynCH, AdAPTIVE GovernanCE And Climate Change (2010); Kenneth R. Young \& Jennifer K. Lipton, Adaptive Governance and Climate Change in the Tropical Highlands of Western South America, 78 CLIMATIC Change 63102 (2006), DOI: 10.1007/s10584-006-9091-9; Folke et al., supra note 189, at 460.
} 
Notably, Rittel and Webber themselves described a form of "cybernetic" adaptive governance as a potential approach to managing the dynamic and complex reality of wicked problems:

Many now have an image of how an idealized planning system would function. It is being seen as an on-going, cybernetic process of governance, incorporating systematic procedures for continuously searching out goals; identifying problems; forecasting uncontrollable contextual changes; inventing alternative strategies, tactics, and time sequenced actions; stimulating alternative and plausible action sets and their consequences; evaluating alternatively forecasted outcomes; statistically monitoring those conditions of the publics and of systems that are judged to be germane; feeding back information to the simulation and decision channels so that errors can be corrected-all in a simultaneously functioning governing process. ${ }^{210}$

While they dismissed this vision as "unattainable," 11 researchers in the $21 \mathrm{st}$ century have begun to document the emergence of adaptive governance in response to new realities of change, ${ }^{212}$ suggesting that this internalization of resilience theory into governance institutions is indeed an improvement in dealing with wicked problems such as climate change and its impacts.

\section{3. $\quad$ Trickster Law to Cope with Wicked Problems}

Law can do more than just allow adaptive governance to emerge; it can also absorb and operationalize cultural narratives that normalize both the resilience theory model of SESs and wicked problems. As noted, both Rittel and Webber, in describing wicked problems, and Holling and Gunderson, in describing ecological panarchy, reached for tricksters as the bridging cultural narrative, and law can, too.

${ }^{210}$ Rittel and Webber, supra note 1, at 159 (emphasis in original).

${ }^{211} \mathrm{Id}$.

212 See Barbara Cosens, THIS VOLUME. See also generally Cosens, Gunderson, \& Chaffin, supra note 181; Brian C. Chaffin, Hannah Gosnell, \& Robin K. Craig, The Emergence of Adaptive Governance in the Klamath River Basin, in BARBARA COSENS \& LANCE GUNDERSON, EDS., Practical Panarchy for Adaptive Water Governance 83-97 (2018); Lisen Schultz, Carl Folke, Henrik Österblom, \& Per Olsson, Adaptive governance, ecosystem management, and natural capital, 112 Proc. NATl. ACAD. SCIENCES (PNAS) 7369-7374 (June 16, 2015), https://doi.org/10.1073/pnas.1406493112; Craig Anthony (Tony) Arnold, Olivia Odom Green, Daniel DeCaro, Alexandra Chase \& Jennifer-Grace Ewa, The Social-Ecological Resilience of an Eastern Urban-Suburban Watershed: The Anacostia River Basin, 51 IDAHO LAW REVIEW 29-90 (2014-2015); Henrik Österblom, \& Carl Folke, Emergence of Global Adaptive Governance for Stewardship of Regional Marine Resources, 18:2 ECOLOGY \& SoCIETY, art. 24 (2013), http://dx.doi.org/10.5751/ES-05373-180204. 
A legal system that thoroughly embraces resilience theory and that promotes adaptive governance, within cultural narratives that also accept change as a part of life, operates as trickster law. ${ }^{213}$ Implementing what I have elsewhere called "principled flexibility," 214 trickster law seeks:

to preserve and enhance the ecological resilience of desirable ecosystem states to climate change and ocean acidification. It employs a precautionary approach to human use of natural resources and seeks to minimize anthropogenic stressors, such as pollution (especially nutrients and toxics), on social-ecological systems. It is cognizant of the planet's limitations and confines human social and economic endeavors within the "safe operating space" of a functional planet. ${ }^{215}$

However, because it is based in resilience theory and panarchy, trickster law also acknowledges that some transformations are and will increasingly become unavoidable, especially as a result of climate change and its multi-faceted impacts. ${ }^{216}$ "Trickster law thus encourages anticipation of and planning for these transformations before they become social-ecological crises. Moreover, it seeks to guide these transformations into new but still productive states, avoiding both ecological stagnation (like eutrophication of lakes) and social-economic collapse as the resource bases of specific communities change."217

Trickster law is a response to managing natural resources in the face of climate change and hence qualifies as a governance proposal for wicked problems. ${ }^{218}$ Like Rittel and Webber, moreover, trickster law focuses on cultural diversity-specifically, on the governance value in natural resource management of "creating space for new voices and new values that can help societies cope with

\footnotetext{
${ }^{213}$ Robin Kundis Craig, Trickster Law: Promoting Resilience and Adaptive Governance by Allowing Other Perspectives on Natural Resource Management, 9 ARIZ. J. ENVTL. L. \& POL’Y 140, 148-49 (2019); Melinda Harm Benson \& Robin Kundis Craig, The End of Sustainability: Resilience AND the Future of ENVIRONMENTAL GOVERnANCE IN the ANTHROPOCENE 48-78, 160-182 (2017).

${ }^{214}$ Robin Kundis Craig, "Stationarity Is Dead"-Long Live Transformation: Five Principles for Climate Change Adaptation Law, 43 HARV. EnVTL. L. REV. 9, 63 (2010).

${ }^{215}$ Craig, supra note 184, at 148 (citing Will Steffen, Katherine Richardson, Johan Rockström, Sarah E. Cornell, Ingo Fetzer, Elena M. Bennett, Reinette Biggs, Stephen R. Carpenter, Wim de Vries, Cynthia A. de Wit, Carl Folke, Dieter Gerten, Jens Heinke, Georgina M. Mace, Linn M. Persson, Veerabhadran Ramanathan, Belinda Reyers, \& Sverker Sörlin, Planetary boundaries: Guiding human development on a changing planet, 347 Science 736, 736 (13 Feb. 2015).

${ }^{216} I d$.

${ }^{217} \mathrm{Id}$.

${ }^{218} \mathrm{Id}$. at $140-41$.
} 
a changing world." 219 As such, it builds from the adaptive governance literature's stress on the importance of polycentricity and pluralism, ${ }^{220}$ deeming it "essential that a diverse array of vested stakeholders eventually participate ...."221 Embracing these other perspectives, moreover, is already yielding improvements in natural resources management and the legal systems that govern that management. ${ }^{222}$

Trickster law thus internalizes both facets of Rittel and Webber's wicked problems, essentially turning that wickedness on its head. Whereas Rittel and Webber identified emerging cultural diversity and social capriciousness as problematic, making it impossible for planners and governance systems to ever fully define and finally solve social issues, trickster law embraces that diversity as a way forward and a means of operationalizing all four of Termeer et al.'s necessary capabilities for dealing with wicked problems. Similarly, whereas Rittel and Webber identified the complexity of systems and ecological panarchy as a source of wickedness, trickster law accepts the adaptive cycle, panarchy, and planetary boundaries models as more accurate representations of reality, refiguring humans and their governance systems as limited agents rather than controlling engineers and embracing adaptive governance as the path of progress.

\section{CONCLUSION}

Problems like climate change are complex, multi-faceted, and evolving, and perhaps rightly deserve the label "wicked." Nevertheless, calling a problem "wicked" also encourages both the experts and the general public to throw up their hands in frustration, abandoning all attempts to cope. ${ }^{223}$

This Article suggests instead that how a person views reality also shapes that person's perception of how intractable wicked problems really are. By offering models of reality that emphasize that change, transformation, and complex multiscalar interactions are normal, resilience theory provides a foundation for adjusting societal capacities, governance systems, and law in ways that allow 21 st-century

${ }^{219} I d$. at 148.

${ }^{220}$ Chaffin, Gosnell, \& Cosens, supra note 181, at 7.

${ }^{221} \mathrm{Id}$. at 8 .

${ }^{222}$ Craig, supra note 213, at 149-56 (providing three examples from the United States and New Zealand of how the incorporation of new values into governance improved natural resources management from an ecological and resilience perspective).

${ }^{223}$ As Jon Kolko notes, "A wicked problem is a social or cultural problem that is difficult or impossible to solve ...." Jon Kolko, Wicked Problems: Problems Worth Solving, STANFORD SOCIAL INNOVATION

REVIEW, https://ssir.org/books/excerpts/entry/wicked problems problems worth solving (March 6, 2012). Notably, his book of the same name explicitly resists the impulse to just give up while simultaneously acknowledging that the impulse is real. Id. 
societies and their institutions to better cope with wicked problems. If Americans can become true resilience thinkers ${ }^{224}$ - this is, if they can increase their capacities for nimbleness, internalize humility in the face of a complex social-ecological reality, ${ }^{225}$ embrace cultural diversity as a source of new perspectives and approaches, and substitute a "whittling away" mentality ${ }^{226}$ for "once and done" goals-21st-century denizens of the United States may discover that wicked problems are not quite that bad, after all.

${ }^{224}$ See generally WALKER \& SALT, supra note 19(providing the classic discussion of what resilience thinking is).

${ }^{225}$ BENSON \& CRAIG, supra note 17 , at 52-56, 158.

${ }^{226}$ See J.B. Ruhl \& James Salzman, Climate Change, Dead Zones, and Massive Problems in the Administrative State: A Guide for Whittling Away, 98 CALIF. L. REV. 59, 66 (2010) (arguing in general for a "whittling away" approach to massive problems, providing a typology for such problems, and concluding that, in order to effectively whittle away at complex massive problems involving tangled causation and cumulative effects, agencies "must be empowered to pool resources with other similarly charged agencies in loosely linked 'weak ties' networks that connect both institutions and people within the institutions"). See also Crowley \& Head, supra note 23 ("Theorists and practitioners agree with Rittel and Webber today that political argumentation is the currency needed to resolve wicked problems, but also that any resolutions are not likely be 'one shot' solutions. They will necessarily be provisional, and so will require adaptation over time.”) 